STEPHEN P. MAGEE*

University of Chicago

\title{
The Welfare Effects of Restrictions on U.S. Trade
}

RECENT ECONOMIC AND POLICY DEVELOPMENTS in the areas of stabilization, allocation, and distribution ${ }^{1}$ help explain the current political mood in some parts of the United States in favor of greater protectionism.

In the area of macroeconomic stabilization, anti-inflationary policies in 1968-71 led to an undesirably high rate of unemployment. For a number of reasons, these had only limited success in reducing the rate of inflation at the hoped-for speed; the result was the price controls imposed on August 15, 1971. The inflation, an increasingly overvalued dollar, and business cycle developments here and abroad placed pressure on both our

* I am grateful to Robert Z. Aliber, Arturo Brillembourg, Stephen Easton, Kevin Ferrell, Stanley Fischer, Frank Flatters, William Hart, Dan Heath, Christine Heckman, Arthur B. Laffer, Carol Nackenoff, Carlos Rodriguez, Osvaldo Schenone, Andrew Schmitz, members of and senior advisers to the Brookings Panel on Economic Activity, the staff of the Council on International Economic Policy and other U.S. government agencies, and members of the Workshop in International Economics at the University of Chicago for assistance and comments on this paper. I am also indebted to the National Science Foundation for financial support. The views expressed here are those of the author and do not necessarily reflect the views of the aforementioned agencies or individuals. The author is responsible for errors that remain. This paper draws heavily from three unpublished working papers by the author: No. 14, "Tariffs and U.S. Trade," A Study for the Council of Economic Advisers (June 1972); No. 15, "Trade Liberalization," A Study for the Council on International Economic Policy (July 1972); and No. 16, "The Welfare Effects of Tariff Reductions in the United States" (August 1972).

1. In The Theory of Public Finance: A Study in Public Economy (McGraw-Hill, 1959), Richard A. Musgrave stresses these areas as a logical division of fiscal policy. 
ability to export and on U.S. industries that compete with imports, depressing the U.S. merchandise trade balance from a $\$ 3.8$ billion surplus in 1967 to a $\$ 2.7$ billion deficit in 1971 .

Second, over the past five years, allocation policy in the international area has changed. The Kennedy Round tariff cuts were staged to reduce U.S. and foreign nonagricultural tariff rates by 35 percent over the period 1968-72, and in a period of increasing overvaluation of the dollar, helped ease the pressure on the U.S. export sector. However, in the importcompeting sector, the U.S. tariff cuts served only to create additional strain. While they were rational on allocational grounds, and relatively small (probably involving only a 3- to 5-percentage-point effect on import prices), their timing unfortunately coincided with an increase in the aggregate unemployment rate from 3.6 percent in January 1968 to 5.9 percent in January 1972.

Third, distribution policy failed to neutralize the shifts occurring in the international sector. The Trade Expansion Act of 1962 provided that parties injured by trade liberalization could receive either adjustment assistance (technical, financial, tax) or import relief through an escape clause, or both. Until recently, because of the wording of the act, the U.S. Tariff Commission has found it difficult to determine that injury to domestic parties was caused "in major part" by tariff concessions. ${ }^{2}$ The result has been an increasing use of "voluntary" restrictive agreements between the United States and countries exporting some sensitive products to us. Nevertheless, if the increased political activities of protectionists are any gauge of the income losses of import-competing industries, the Trade Expansion Act of 1962 and subsequent policy have failed to compensate adequately for

2. See, for example, Tracy W. Murray and Michael R. Egmand, "Full Employment, Trade Expansion and Adjustment Assistance," Southern Economic Journal, Vol. 36 (April 1970), pp. 404-24, for a discussion of these difficulties. In "Policy Problems in the Adjustment Process (U.S.)" (paper delivered to the Seminar on Industrialization and Trade Policies in the 1970s, International Bank for Reconstruction and Development, October 1972; processed), Robert E. Baldwin and John H. Mutti note that from October 1962 to November 1969, all twenty-six petitions to the U.S. Tariff Commission by industries, firms, and workers were denied. From November 1969 to March 1972, 16 out of 108 cases involving workers' adjustment assistance heard by the commission were decided in favor of the workers while in another 28 cases the votes were evenly divided; 15 out of 23 cases involving firms were even or decided in favor of the firm while 7 out of 10 industry-wide cases were decided in favor of the industry. (In case of a tied vote, the President decides whether to accept or reject the petition.) 
shifts in the distribution of income occasioned by trade liberalization, and intensified by high domestic unemployment. ${ }^{3}$

Thus, stabilization policy in recent years has fallen short of the goals of slowing inflation, avoiding high unemployment, and attaining external equilibrium. On the other hand, a rational allocation policy of reciprocal tariff reduction was successfully implemented. Both of these policies, however, led to a redistribution of income away from resources in importcompeting industries. Leaving aside the question of whether these resources should be compensated, the existing policy mechanisms for handling redistribution problems in the international sector probably did not compensate these resources sufficiently to eliminate their losses relative to the rest of the economy.

Regardless of the cause, certain groups continue to urge increased protection. Should U.S. imports be restricted to obtain a higher level of aggregate employment or a distribution of income more favorable to the factors of production in import-competing industries? More important, can welfare be increased in the United States as a whole with greater protection? The purpose of this paper is to provide some rough estimates of the welfare effects in the United States of both existing protection and greater protection. To use a concrete example of the possibilities for increased protection, I shall examine Title III of a widely discussed bill introduced by Senator Vance Hartke of Indiana and Representative James A. Burke of Massachusetts, in the Ninety-second Congress. ${ }^{4}$

The first section presents a general discussion of free trade and the appropriateness of trade restrictions as tools of government policy. The second section considers the welfare costs of existing trade restrictions and provides a framework for the analysis of the Burke-Hartke proposal ${ }^{5}$

3. The act does not provide for assistance to export- or import-competing sectors due to overvaluation of the dollar or the recent cyclical developments that have affected the U.S. trade position. Also, it is possible that the problems of import-competing areas are attributable largely to the aggregate level of unemployment and that this sector is attempting to use trade policy to improve its position, an option not open to the nontraded goods sector.

4. S. 2592 and H.R. 10914, 92 Cong. 1 sess., both introduced September 28, 1971.

5. Several important works on trade restrictions are used frequently in this analysis: Baldwin and Mutti, "Policy Problems"; Giorgio Basevi, "The Restrictive Effect of the U.S. Tariff and Its Welfare Value," American Economic Review, Vol. 58 (September 1968), pp. 840-52; W. M. Corden, The Theory of Protection (Oxford: Clarendon Press, 1971); Harry G. Johnson, Aspects of the Theory of Tariffs (London: George Allen and 
in the third section. The final sections provide first some caveats and then a summary.

\section{Free Trade vs. Restrictions}

\section{MOTIVATIONS FOR FREE TRADE}

The primary motivation for free trade is that it permits a country to import products that can be produced cheaply abroad in exchange for products that can be produced cheaply at home. Two primary gains arise from international trade, the consumption gain and the production gain. ${ }^{6}$ The first arises because consumers can purchase goods at a list of world prices that are below the internal prices that would prevail in the absence of trade, the second from the ability of producers to shift their activity toward products in which they are relatively efficient. Both gains increase consumer welfare since trade increases income and provides consumers with an alternative set of market prices. In principle, a country's tradeable products can be ranked from those of greatest comparative advantage to those of least. The country obtains both the production and consumption gains from trade by increasing production and exporting those high on the list and reducing production and importing those low on the list. If foreigners place tariffs on the exports of a country and that country places tariffs on imported goods, the gains from free trade and specialization in production are reduced. If each tariff level is sufficiently high, trade will cease altogether and the country will revert to the welfare position it would have had in the absence of trade.

The proposition that tariffs can offset the benefits of comparative advantage in a multiple-product context has been illustrated in a study of 1937

Unwin, 1971); Ilse Mintz, U.S. Import Quotas: Costs and Consequences, AEI Domestic Affairs Study 10 (American Enterprise Institute, forthcoming); Robert M. Stern, "The U.S. Tariff and the Efficiency of the U.S. Economy," in American Economic Association, Papers and Proceedings of the Seventy-sixth Annual Meeting, 1963 (American Economic Review, Vol. 54, May 1964), pp. 459-70; Robert M. Stern, "Tariffs and Other Measures of Trade Control: A Survey of Recent Developments," Journal of Economic Literature, forthcoming; and U.S. Department of Agriculture, Economic Research Service, Measures of the Degree and Cost of Economic Protection of Agriculture in Selected Countries, Technical Bulletin 1384 (1967).

6. See Harry G. Johnson, "The Cost of Protection and the Scientific Tariff," Journal of Political Economy, Vol. 68 (August 1960), pp. 327-45, reprinted in Johnson, Aspects of the Theory of Tariffs. 
trade by MacDougall. He showed that in product areas in which the United States had a comparative advantage, U.K. tariff rates were high and that U.S. tariff rates were high in areas where the United Kingdom had a comparative advantage. ${ }^{7}$ Relatively high average tariff rates in the United States held the U.S. share of U.K. exports of manufactures to only 4.5 percent, while 11 percent of U.S. exports of manufactures went to the United Kingdom in 1937. Thus, tariffs largely dissipated the bilateral gain to trade between the two countries.

If the world moved to free trade in manufactured products, what resources would the United States be able to utilize more efficiently? Since the United States has large endowments of skilled labor and of research and development facilities relative to the rest of the world, restrictions on the country's exports reduce its ability to exploit its comparative advantage by exporting products using such resources. ${ }^{8}$ On the import side, since the United States has little semiskilled and unskilled labor relative to the rest of the world, import-competing industries presumably will tend to release relatively more of this type of labor. In 1967, manufacturing wage rates in import-competing industries were only $\$ 2.66$ per hour (excluding quota items) compared with $\$ 2.84$ in all manufacturing and $\$ 3.16$ in the export industries. ${ }^{9}$ Also, Ball has offered 1962 cross-sectional evidence that effective rates of protection are high in low-wage areas and vice versa. ${ }^{10}$ Thus,

7. G. D. A. MacDougall, "British and American Exports: A Study Suggested by the Theory of Comparative Costs," Economic Journal, Vol. 61 (December 1951), pp. 697-724. The unweighted average for U.S. tariffs was 61 percent ad valorem where the United Kingdom had a comparative advantage and 28 percent where she did not.

8. See, for example, William Gruber, Dileep Mehta, and Raymond Vernon, "The R\&D Factor in International Trade and International Investment of United States Industries," Journal of Political Economy, Vol. 75 (February 1967), pp. 20-37; and Donald B. Keesing, "The Impact of Research and Development on United States Trade," in the same issue, pp. 38-48.

9. All manufacturing is from Trade Relations Council of the United States, Inc., Employment, Output, and Foreign Trade of U.S. Manufacturing Industries, 1958-69/70 (4th ed., Washington: TRC, 1972), Vol. 2, p. 793. Other wage rates were calculated by Kevin Ferrell. Actually, to prove that import-competing industries are relatively intensive in unskilled labor, the share of factor rewards going to unskilled labor in such industries should exceed their share in the rest of the economy. The evidence that this might be the case is Stage III (the standardized product) of Raymond Vernon's product cycle ("International Investment and International Trade in the Product Cycle," Quarterly Journal of Economics, Vol. 80, May 1966, pp. 190-207).

10. David S. Ball, "United States Effective Tariffs and Labor's Share," Journal of Political Economy, Vol. 75 (April 1967), pp. 183-87. The figure on p. 185 shows the relationship dramatically. 
elimination of U.S. and foreign tariffs would shift relative demand in the United States from low-wage to high-wage labor and permit greater utilization of U.S. technology.

\section{REASONS FOR TRADE RESTRICTIONS}

Although tariffs and quotas eliminate the welfare gains from trade, they exist because they serve goals in at least six areas: domestic-political income redistribution, employment, the balance of payments, international income redistribution, infant industries, and other social goals. We shall consider each in turn.

Domestic distribution of income. In 1941, Stolper and Samuelson showed that if wages and prices are flexible so that full employment can be maintained, an increase in tariff levels would decrease the real income of the factor used relatively intensely in export production and increase the real income of the factor used relatively intensely in import-competing industries. ${ }^{11}$ Since, by the Heckscher-Ohlin theorem, a country tends to export products that use relatively intensely its abundant factor, higher U.S. tariffs would tend to decrease the income of the abundant factor-skilled labor-and increase the income of the scarce factor-semiskilled and unskilled labor. This effect would be accentuated by any foreign retaliation on U.S. exports. The impact of restricted trade on the returns to both capital and land are unclear; ${ }^{12}$ but to the extent that foreign barriers to U.S. exports of agricultural goods could be reduced, the return to land should increase. In the short run, before relative factor prices can adjust fully, trade liberalization by the United States would tend to increase utilization of skilled labor and land while reducing the utilization of unskilled labor.

Assuming that the nation wishes to increase the income of factors in import-competing industries, the use of trade restrictions depends on the welfare costs they impose on the United States relative to those of alternative programs such as subsidies or excise taxes. In a welfare sense, trade

11. Wolfgang F. Stolper and Paul A. Samuelson, "Protection and Real Wages," Review of Economic Studies, Vol. 9 (November 1941), pp. 58-73.

12. See, for example, Wassily Leontief, "Domestic Production and Foreign Trade; the American Capital Position Re-examined," Economia Internazionale, Vol. 11 (February 1954), pp. 3-32, reprinted in Richard E. Caves and Harry G. Johnson (eds.), Readings in International Economics (Richard D. Irwin, 1968), Vol. 11, Chap. 30. See also the discussion by William H. Branson and Helen B. Junz, "Trends in U.S. Trade and Comparative Advantage," Brookings Papers on Economic Activity (2:1971), pp. 285-338. 
restrictions are generally less efficient than alternative mechanisms of redistributing income.

Aggregate employment. Tariffs can add to total employment by stimulating job creation in import-competing industries if the economy is at less than full employment. At full employment, the relative price change for importables simply alters the composition of employment and not the aggregate level if stabilization policy keeps the economy at the same point on a fixed Phillips curve. However, trade restrictions are an inappropriate means of stimulating aggregate employment. First and foremost, they cannot be as efficient as the macroeconomic tools of monetary and fiscal policy. Second, the aggregate impact of trade restrictions may be offset by foreign retaliation. For example, Congress was influenced by the unemployment problem when it passed the Tariff Act of 1930, which increased duties on more than one thousand articles of trade. ${ }^{13}$ Within a year twentyfive foreign countries had raised their tariffs against American goods in a tariff war. Between 1929 and 1933 international trade declined from $\$ 65$ billion to less than $\$ 25$ billion a year, reflecting both declining incomes and increased restrictions. ${ }^{14}$

Trade balance and balance of payments. An increase in import prices caused by a tariff directly reduces the value of imports and improves the trade balance. Several factors modify this effect, however. First, retaliation against the country's exports may result. Second, there are indirect reductions in the value of exports through several mechanisms: The rise in the price of imports discourages production of goods that use these imports as inputs, encourages the movement of factors into the import-competing sector, and raises the prices of exports and nontraded goods. Finally, the reduction in the value of imports into a country reduces the foreign exchange earnings of the rest of the world and thus the country's exports.

The use of the tariff as a means of improving the trade balance and the balance of payments is symptomatic of the failure of other, more general, mechanisms to achieve international adjustment of payments imbalances. ${ }^{15}$ There is good reason to be skeptical about the uses of tariffs for providing

13. Robert M. Norris, "U.S. Foreign Economic Policy-Progress or Regression?" (speech delivered at the annual spring meeting of the New Hampshire Bankers Association, June 7, 1972; processed).

14. N. H. Engle, "Reciprocity in Foreign Trade Policy," Harvard Business Review, Vol. 16 (Autumn 1937), p. 42.

15. See Stern, "Tariffs and Other Measures of Trade Control." 
long-run solutions to countries' balance-of-payments disequilibria. Since these disequilibria may be simple monetary phenomena, tariffs may not be the most appropriate way to approach the problem. If, as monetarists argue, a balance-of-payments deficit is evidence that domestic credit creation exceeds the growth in the domestic demand for cash balances, the proper response to the deficit would be to slow the growth of domestic credit creation. ${ }^{16}$ Of course, there are difficulties in applying to a reserve-currency country such as the United States the monetary approach to the balance of payments. But similar arguments hold for other approaches to the balance of payments. Policies such as greater flexibility in foreign exchange rates within the band or fully floating rates would obviate the need for tariffs as policy tools for balance-of-payments purposes.

The optimum tariff. If a country is able to influence world prices through the volume of its trade, it can increase its welfare in some cases by levying a tariff, bringing welfare to a maximum by a rate that is called an "optimum tariff." At its optimum level the tariff can assure welfare gains from improving the terms of trade that more than offset the losses caused by the distortion in domestic production and consumption. In a sense, it operates like a tax on foreigners, lowering the net price they receive on items they sell. Harry G. Johnson has shown that the welfare gains from an optimum tariff are smaller, the smaller the share of imports in free trade in an economy and the more elastic the foreign offer curve facing the country. ${ }^{17}$ Since the United States has a relatively small ratio of imports to domestic production and foreign demand is somewhat elastic, the gains to the United States from an optimal tariff would be relatively small. Table 1, reproduced from Johnson's article, shows, for example, that if the elasticity of foreign demand for U.S. products were 2.0 and the free trade import share were 0.10 , the optimal tariff for the United States would be 100 percent but would yield a percentage gain in U.S. welfare of only 1.4 percent. Such a policy is infeasible for several reasons, such as international political costs and the likelihood of foreign retaliation, which are ignored in Table 1. In practice, the attempt of any one country to improve its welfare at the ex-

16. Harry G. Johnson, "The Monetary Approach to Balance of Payments Theory," forthcoming in Michael B. Connolly and Alexander K. Swoboda, International Economics: The Geneva Essays (London: Allen and Unwin, 1972).

17. Harry G. Johnson, "The Gain from Exploiting Monopoly or Monopsony Power in International Trade," Economica, Vol. 35, New Series (May 1968), pp. 151-56, reprinted in Johnson, Aspects of the Theory of Tariffs. 
Table 1. Relative Welfare Gain from Optimum Tariff Policies

Percent

\begin{tabular}{|c|c|c|c|c|c|c|c|c|c|c|c|}
\hline \multirow{2}{*}{$\begin{array}{c}\text { Elasticity } \\
\text { of foreign } \\
\text { demand }\end{array}$} & \multirow{2}{*}{$\begin{array}{l}\text { Optimum tariff } \\
\qquad \begin{array}{c}t=\frac{100}{\eta-1} \\
(\text { percent })\end{array}\end{array}$} & \multicolumn{10}{|c|}{ Import share under free trade } \\
\hline & & 0.05 & 0.10 & 0.15 & 0.20 & 0.25 & 0.30 & 0.35 & 0.40 & 0.45 & 0.50 \\
\hline 1.10 & 1000 & 3.4 & 6.7 & 9.9 & 12.8 & 15.3 & 18.1 & 20.3 & 22.8 & 23.7 & 24.8 \\
\hline 1.20 & 500 & 2.6 & 5.1 & 7.4 & 9.6 & 11.7 & 13.5 & 15.0 & 16.3 & 17.3 & 18.0 \\
\hline 1.30 & $3331 / 3$ & 2.1 & 4.1 & 6.0 & 7.6 & 9.2 & 10.6 & 11.7 & 12.6 & 13.4 & 13.8 \\
\hline 1.40 & 250 & 1.8 & 3.4 & 4.9 & 6.3 & 7.5 & 8.6 & 9.5 & 10.2 & 10.7 & 11.1 \\
\hline 1.50 & 200 & 1.5 & 2.8 & 3.8 & 5.2 & 6.2 & 7.1 & 7.8 & 8.4 & 8.9 & 9.1 \\
\hline 1.75 & $133^{1 / 3}$ & 0.9 & 1.8 & 2.5 & 3.4 & 4.1 & 4.7 & 5.2 & 5.6 & 5.8 & 6.1 \\
\hline 2.00 & 100 & 0.7 & 1.4 & 2.0 & 2.6 & 3.1 & 3.4 & 3.8 & 4.1 & 4.3 & 4.4 \\
\hline 2.25 & 80 & 0.6 & 1.1 & 1.5 & 2.0 & 2.3 & 2.6 & 2.9 & 3.1 & 3.2 & 3.3 \\
\hline 2.50 & $66^{2 / 3}$ & 0.5 & 0.9 & 1.2 & 1.6 & 1.8 & 2.1 & 2.3 & 2.4 & 2.5 & 2.6 \\
\hline 2.75 & $571 / 4$ & 0.4 & 0.7 & 1.0 & 1.3 & 1.5 & 1.7 & 1.8 & 1.9 & 2.0 & 2.1 \\
\hline 3.00 & 50 & 0.3 & 0.6 & 0.8 & 1.0 & 1.2 & 1.4 & 1.5 & 1.6 & 1.7 & 1.7 \\
\hline 3.50 & 40 & 0.2 & 0.4 & 0.6 & 0.7 & 0.9 & 1.0 & 1.1 & 1.1 & 1.2 & 1.2 \\
\hline 4.00 & $331 / 3$ & 0.2 & 0.3 & 0.4 & 0.6 & 0.7 & 0.7 & 0.8 & 0.9 & 0.9 & 0.9 \\
\hline 4.50 & 2847 & 0.1 & 0.2 & 0.3 & 0.4 & 0.5 & 0.6 & 0.6 & 0.7 & 0.7 & 0.7 \\
\hline 5.00 & 20 & 0.1 & 0.2 & 0.3 & 0.4 & 0.4 & 0.5 & 0.5 & 0.5 & 0.6 & 0.5 \\
\hline
\end{tabular}

Source: Reproduced from Harry G. Johnson, "The Gain from Exploiting Monopoly or Monopsony Power in International Trade," Economica, Vol. 35, New Series (May 1968), p. 156, reprinted in Harry G. Johnson, Aspects of the Theory of Tariffs (London: George Allen and Unwin, 1971).

pense of another is likely to result merely in a deterioration in the welfare of both through escalating restrictions.

"Infant industry." According to the infant industry argument, tariffs can be levied on manufactured and other products to encourage industrialization of the country. ${ }^{18}$ Once the "infant" has matured into a strong economic entity, the trade restrictions are removed. A long-run gain can accrue from the trade restriction only if the tariff stimulates a change in the country's endowment or quality of factors, increases its technical capability through learning by doing or some other process, or allows it to exploit potential economies of scale. Even if economic gains are achieved through tariffs, but are delayed, their present discounted value may be less than the present value of the costs imposed by the tariff. ${ }^{19}$

18. It is questionable whether the "infant industry" argument applies to the United States in the current protectionist debate. As one wit has put it, most of the U.S. industries arguing for greater protection are in their dotage rather than their infancy.

19. Nevertheless, a number of countries have established "tariff factories" by placing high tariffs on finished products and low tariffs on inputs. The "effective rate of protection" indicates the protection provided to the manufacture of the finished product. For example, in order to provide protection for an industrial process such as automobile assembly, the tariff on imports of autos must be compared with the tariffs on all components of automobile production. If there are high tariffs on imports of automobile components, there will be no encouragement of automobile assembly in the country. The "effective rate of protection" is defined as the percentage change in value added in some activity that is attributable to the entire tariff structure. In the introduction to a paper by Humphrey, there is an excellent review of the literature on the effective rate of protection 
Other social goals. Many other reasons are given for trade restrictions, such as maintaining domestic production at high levels in certain sectors for national defense purposes, protecting the safety and health of domestic consumers and the environment, and generally controlling the flows of individual products. Bhagwati has shown that whenever the government is determined to achieve a social goal, the optimal strategy is to use policy variables that affect the target variable most directly. ${ }^{20}$ For example, trade restriction through a tariff or quota is inefficient since it is equivalent to the simultaneous introduction of a production subsidy and a consumption tax. Trade restrictions, therefore, would be optimal only where these two things are desirable simultaneously and, by coincidence, are desirable at the same ad valorem rate. Even apart from this bizarre case, it is difficult to construct cases in which society wishes both to tax consumption and to stimulate production of a given product.

In the case of the infant industry that the country wishes to encourage, a production subsidy is demonstrably superior to a tariff in that it does not artificially raise the price to consumers. At times, the most efficient use of government resources would be to affect directly the country's factor endowment. In short, if the social goal is to reduce consumption of a given product, a consumption tax is superior to tariffs; if it is to stimulate production, a production subsidy is superior to the tariff.

In summary, each of the six objectives of trade restrictions could potentially be achieved more efficiently through other policy tools. Although the arguments for trade restrictions are economically weak, the political reasons for their existence are more persuasive. First, import-competing industries

(see David B. Humphrey, "Demand Inflation and Effective Protection," Southern Economic Journal, Vol. 37, October 1970, pp. 144-50). The effective rate of protection is measured as the ad valorem tariff on the final product less the tariff on the material inputs into the product weighted by their importance; both terms are then adjusted for the importance of all material inputs into the final product. The general tendency of countries to place higher tariffs on manufactures of finished goods as opposed to raw materials is reflected in recent data published by GATT. See The Contracting Parties to the General Agreement on Tariffs and Trade, Basic Documentation of Tariff Study, Summary Tables (Geneva: The Contracting Parties, July 1970). The GATT study shows that the average ad valorem tariff rates in the major industrial countries (calculated by weighting each country's tariffs by its trade) is 6.2 percent for raw materials, 9.0 percent for semimanufactures, and 10.4 percent for finished manufactures.

20. For the most comprehensive survey of the optimal policy tools to use in a given situation, see Jagdish N. Bhagwati, "The Generalized Theory of Distortions and Welfare," in Jagdish N. Bhagwati and others (eds.), Trade, Balance of Payments and Growth: Papers in International Economics in Honor of Charles P. Kindleberger (Amsterdam: North-Holland, 1971). 
prefer them to the more direct form because of the anonymity and lower visibility of subsidization they provide. Second, trade restrictions are politically attractive since they simultaneously generate government revenue, subsidize producer interests that are well-organized politically, and tax consumer interests that, until lately, have not been effectively organized. Third, the optimum tariff argument may be in the back of politicians' minds when a tariff is levied: They hope that foreigners and not domestic residents will bear the "incidence" of the tax.

It is reassuring that substitutability within the economic system provides some offset to the welfare losses imposed by trade restrictions. Mundell has shown that even if international commodity movements are completely stopped by tariffs or quotas, a small country may avoid any loss of welfare if there is free movement of at least one factor of production. ${ }^{21}$ Thus, even if protectionists in the United States succeeded in stopping all international trade, under some fairly restrictive assumptions, U.S. residents might still be able to attain the free trade welfare level if (contrary to fact) either (1) free immigration or (2) free movements of capital were permitted. Thus, some of the welfare losses imposed by trade restrictions may be undone by factor mobility.

Given these arguments on both sides of the tariff question, what has been the historical pattern of tariff levels in the United States? Figure 1 shows that from early in the century until the early twenties, tariff rates were falling. The rates rose in the 1920s with the Fordney-McCumber tariff and again in the 1930s under Smoot-Hawley. Since then, there has been a gradual movement to freer trade.

\section{The Welfare Effects of Moving to Free Trade}

\section{A FRAMEWORK FOR ANALYZING THE WELFARE EFFECTS}

As noted at the outset, international trade confers on a country two advantages, both of which increase its real income: (1) an expansion of its consumption opportunities, and (2) a shift of its resources into more productive areas. One way of quantifying these gains is through consumers' surplus and producers' surplus, as illustrated in Figure 2. The panel on consumers' surplus reveals that, if the product were sold on a unit-by-unit

21. Robert A. Mundell, "International Trade and Factor Mobility," American Economic Review, Vol. 47 (June 1957), pp. 321-35. 


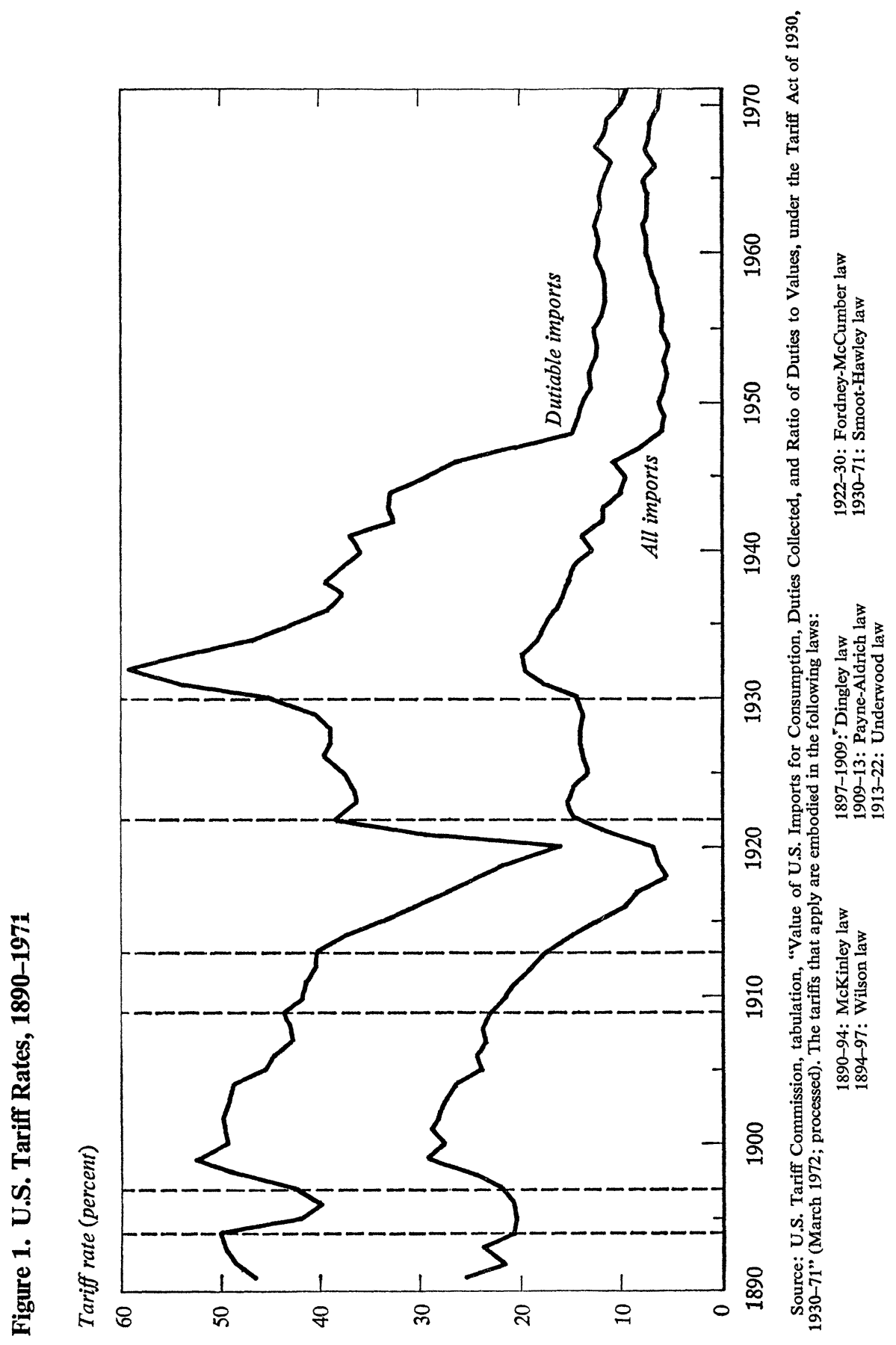


Figure 2. Measurement of Consumers' and Producers' Surpluses
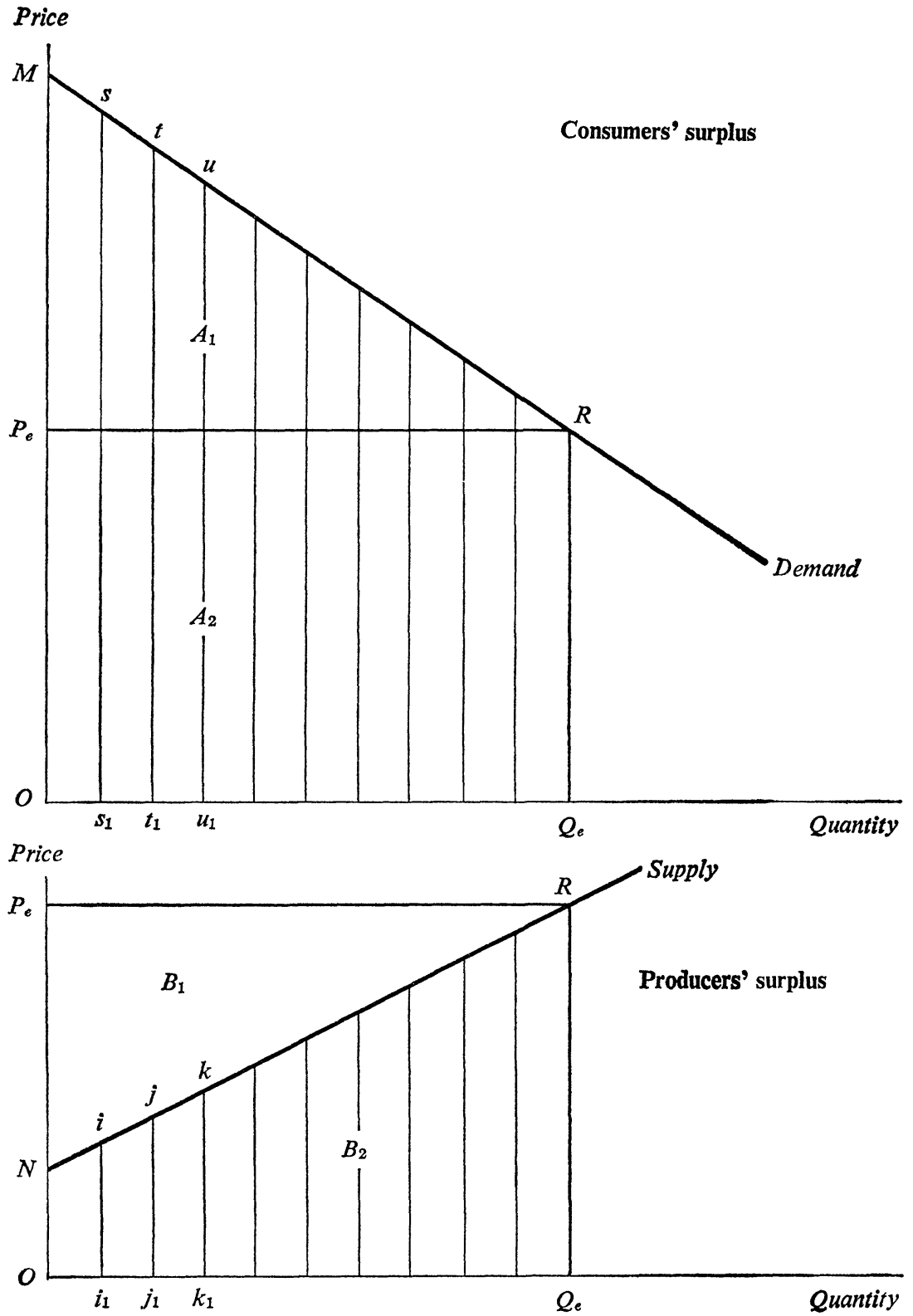
basis, and the price exceeded $O M$, no units would be sold. If one unit were sold, someone would be willing to pay $s s_{1}$; the second unit could be sold for $t t_{1}$, the third unit for $u u_{1}$, and so on. If the price is $O P_{e}$, the amount people would be willing to pay on a unit-by-unit basis is equal to the area $O Q_{e} R M$. However, since everyone pays the same price for each unit sold, the actual payment for $O Q_{e}$ is equal to the area $O Q_{e} R P_{e}$, or area $A_{2}$. The residual region, $A_{1}$, is called the "consumers' surplus." As the price falls, this area becomes larger, and consumers are better off. The concept of producers' surplus is similar. At a market price below $O N$, suppliers are not willing to provide any output. If the price is equal to $i i_{1}$, one unit would be forthcoming, a second if the price were raised to $j j_{1}$, and so forth. Thus, on a unit-by-unit basis, suppliers would be willing to supply $O Q_{e}$ if they received area $B_{2}$ as their total receipts. However, if $O P_{e}$ is the market price, the actual receipts of suppliers equal the areas $B_{1}+B_{2}$. Thus, producers receive a "producers' surplus" equal to area $B_{1}$. This partial equilibrium approach can be extended to a general equilibrium context in the twosector model by using compensated demand curves and general equilibrium supply curves (that is, the vertical axis expresses a price ratio).

The use of consumers' surplus and producers' surplus as measures of the welfare costs of trade restrictions is illustrated in Figure 3.22 Assume that the United States is importing a product whose world price is equal to $O P_{w}$. The U.S. domestic demand and supply curves for the product are shown in the figure. With no restrictions on U.S. imports, domestic demand would equal $O Q_{2}^{\prime}$, with $O Q_{2}$ produced by U.S. producers and $Q_{2} Q_{2}^{\prime}$ the quantity imported. The consumers' surplus would then be the triangular area $M S P_{w}$ and the producers' surplus would be area $H_{1}$. If a tariff is now imposed on imports of the product but the world price stays fixed, the U.S. price rises to $O P_{u s}$. The ad valorem tariff is equal to the ratio of $P_{u s} P_{w}$ to

22. One analytical problem with these welfare measures is that the imports under consideration include both consumer goods and intermediate goods while the traditional theory deals only with consumer goods. However, Richard Schmalensee, in "Consumer's Surplus and Producer's Goods," American Economic Review, Vol. 61 (September 1971), pp. 682-87, finds that in the constant costs-perfectly competitive case, if the ratio between intermediate and final goods is fixed, the traditional consumers' surplus approach yields an accurate measure of the social welfare effects. If the ratio is not fixed, so that the lower price caused by a tariff decrease causes the ratio to change, the traditional measure overstates the true welfare gain in the competitive case and understates the social gain in the monopoly case. Since import markets probably fall somewhere between the perfectly competitive and the monopoly cases, there is no reason to expect the estimate here to be too high or too low because of the intermediate goods problem. The one caveat is that Schmalensee deals only with the constant costs case. 


\section{Figure 3. The Welfare Costs of Tariffs}

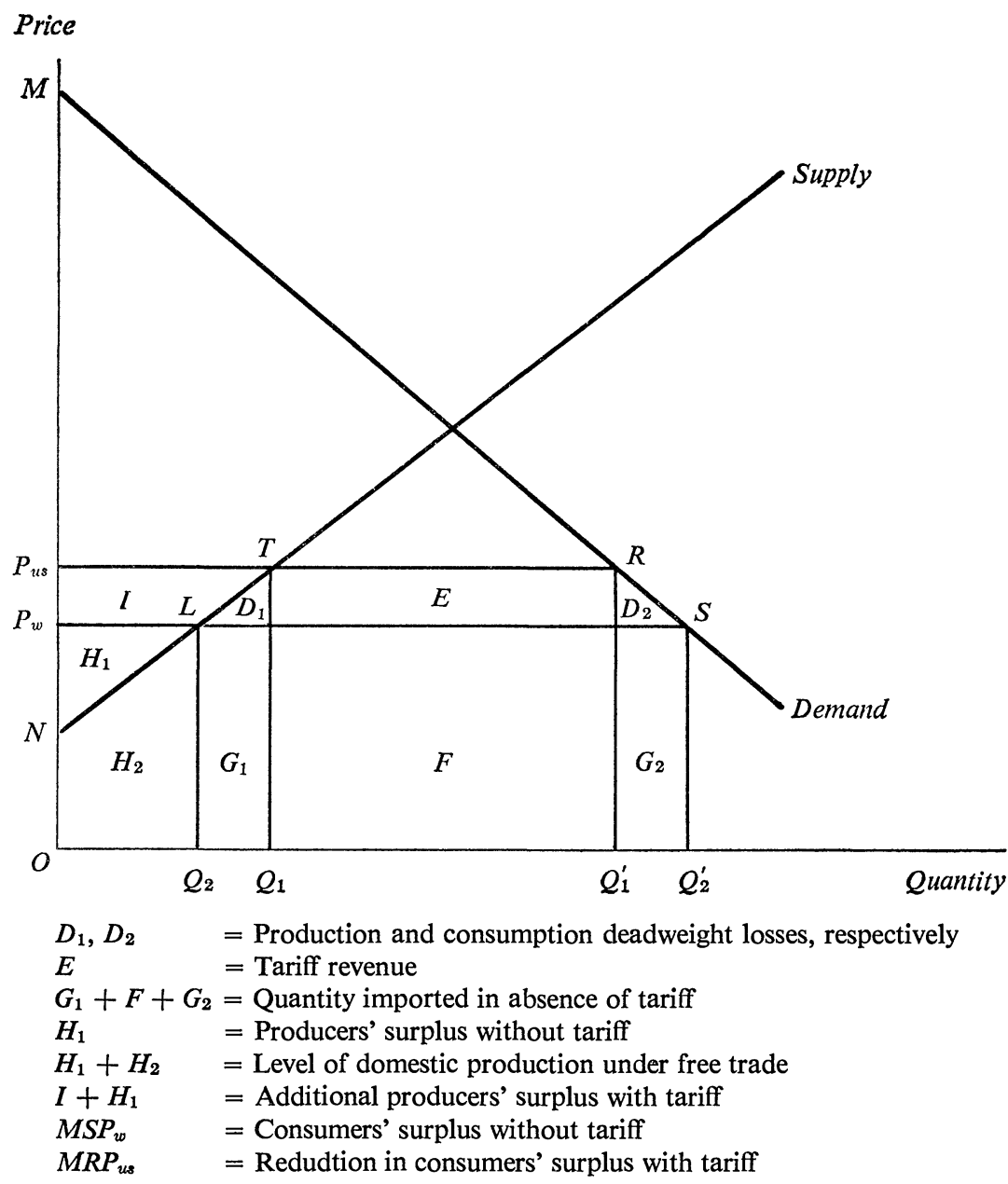

$O P_{w}$. Notice that the amount of consumer surplus is reduced by the area $P_{w} S R P_{u s}$. What happens to this decrease in the value of consumer welfare? First, the trapezoidal area $I$ is transferred to producers' surplus, so that import-competing producers earn windfall gains. Second, area $E$ becomes tariff revenue and is transferred from consumers of import-competing products to the government (area $E$ equals the tariff rate $P_{w} P_{u s}$ times the quantity of imports $Q_{1} Q_{1}^{\prime}$ under the tariff). Thus, two of the main components of the reduction in the welfare of consumers are simply a transfer to other U.S. citizens: $I$ is the redistribution effect to producers and $E$ the 
revenue effect. However, two portions of the reduction in consumers" surplus are captured by no one. These are the triangular areas $D_{1}$ and $D_{2}$, and they are known as the "deadweight losses" caused by the tariff. Area $D_{1}$ corresponds to the production deadweight loss, which results from an artificial movement of resources from higher- to lower-productivity pursuits; and $D_{2}$ is the consumption deadweight loss, which reflects substitution of less satisfactory products by consumers. The subsequent investigation concentrates on areas $D_{1}$ and $D_{2}$, the sum of which measures the total social costs to U.S. consumers of U.S. trade restrictions. ${ }^{23}$

The deadweight loss triangles in Figure 3 are annual flows; that is, these losses are incurred every year. In analyzing the welfare effects of moving toward free trade, the gains through the reduction in the inefficiencies $\left(D_{1}\right.$ and $D_{2}$ ) must be adjusted for the costs of moving resources from importcompeting industries into other areas. This involves calculating the present discounted value of both the perpetual annual deadweight losses of welfare and the costs of moving resources out of import-competing production and into other areas. ${ }^{24}$ The initial assumption is that neither the demand nor the supply of the product in question is growing; this assumption is later relaxed. The long-run supply elasticity will, however, exceed the short-run supply elasticity. Thus, the production deadweight loss, $D_{1}$, becomes larger

23. See W. M. Corden, "The Calculation of the Cost of Protection," Economic Record, Vol. 33 (April 1957), pp. 29-51; Basevi, "Restrictive Effect of the U.S. Tariff"; Stern, "U.S. Tariff and the Efficiency of the U.S. Economy"; and Franklin V. Walker, "The Restrictive Effect of the U.S. Tariff: Comment," American Economic Review, Vol. 59 (December 1969), pp. 963-66. The use of these triangles as measures of the welfare costs of trade restrictions has been discussed extensively by Johnson in "Cost of Protection and the Scientific Tariff." The theoretical underpinnings of these measures of welfare have been discussed extensively in Arnold C. Harberger's work; see, for example, "The Measurement of Waste," in American Economic Association, Papers . . . 1963, pp. 58-76. The rather strong assumptions necessary for the use of this technique and all of its theoretical difficulties will not be discussed here. The discussions by Dale W. Jorgenson, William Vickrey, Tjalling C. Koopmans, and Paul A. Samuelson, in response to Harberger's paper and appearing in the same Papers (pp. 86-96), refer to a number of these difficulties.

One set of sufficient conditions for consistent additivity of individual preference maps into community preference maps is that all individuals have identical and homothetic preferences. The measures used here also imply that the marginal utility of income is the same across individuals and at all income levels.

24. For intertemporal approaches to deadweight losses, see D. Levhari and E. Sheshinski, "Lifetime Excess Burden of a Tax," Journal of Political Economy, Vol. 80 (January/February 1972), pp. 139-47, and Baldwin and Mutti, "Policy Problems." I am especially indebted to the Baldwin and Mutti paper for suggesting the discounting of both benefits and adjustment costs. 
through time. In Figure 3, this means that the point $L$, which is the intersection of the supply curve and the world price line, will move to the left as the supply curve rotates through $T$ and adjusts to its long-run position. For most consumer products, the long-run demand elasticity will exceed the short-run demand elasticity. ${ }^{25}$ Thus, the long-run consumption deadweight loss, $D_{2}$, will be larger than the short-run deadweight loss. The sizes of the two deadweight loss flows increase until the new long-run equilibrium is reached, and thereafter the two triangles remain at a constant size in the absence of growth. Since the losses are changing through time, discounting them is instructive since it reduces the changing flows to a single present value; thus, the costs of tariffs can be compared with the present values of alternative policies.

The welfare gains from tariff elimination must be adjusted for the costs of moving factors from the import-competing sector into other areas. The largest component of this cost is the unemployment of factors of production during a transition period from the time the factors leave the import-competing industry until they are reemployed. These costs are incurred only until a new long-run supply equilibrium is achieved; at that point resource flows cease and hence no further costs arise from the movement of resources. In this paper, the relocation costs of labor will be used as a proxy for the general costs of relocation. There are serious difficulties in calculating the costs of moving capital that is quasi-specific to importcompeting production. As a result, the "lost labor time" measure will understate the total social cost of the resource movement, just as the deadweight loss triangles understate the costs of trade restrictions (some of the nonquantifiable losses are discussed below).

\section{COSTS OF EXISTING RESTRICTIONS ON U.S. IMPORTS}

What are the annual costs of existing restrictions on U.S. trade? This section analyzes the impact on U.S. imports, considered in three categories: those that compete directly with U.S. production and are subject to tariffs;

25. However, H. S. Houthakker and Lester D. Taylor, in Consumer Demand in the United States, 1929-1970: Analyses and Projections (2d ed., Harvard University Press, 1970), show that in cases where inventory adjustments are present, the long-run demand elasticity for products can be less than the short-run elasticity. But on balance they find that the "habit formation" phenomenon generally dominates the "inventory adjustment" phenomenon, so that the long-run demand elasticities exceed the short-run elasticities.

I assume that producers and consumers are in long-run equilibrium at points $T$ and $R$ in Figure 3, so that the supply and demand curves rotate through these points. 
Table 2. Value of U.S. Imports and Duties Paid on Major Products Subject to Quantitative Restrictions, 1971

Millions of dollars

\begin{tabular}{lcc}
\hline \multicolumn{1}{c}{ Product } & Imports & Duties \\
\hline Petroleum & 3,278 & 100 \\
Steel $^{\mathbf{s}}$ & 2,009 & 126 \\
Man-made and woolen textiles $^{\prime}$ & 1,840 & $\ldots$ \\
Sugar & 813 & 48 \\
Meat & 598 & 34 \\
Cotton textiles & 590 & $\ldots$ \\
Dairy & 70 & $\ldots$ \\
Stainless steel flatware & 28 & $\ldots$ \\
Cotton and cotton waste & 8 & $\ldots$ \\
Wheat & 0.4 & $\ldots$ \\
Peanuts & 0.4 & $\ldots$ \\
Total & 9,235 & 308 \\
\hline
\end{tabular}

Sources: All data except for steel were supplied by Mary Jane Wignot, Office of the Special Representative for Trade Negotiations. Steel data, which are from the Trade Relations Council of the United States, Inc., are for 1969 and are for standard industrial classification (SIC) 3312 only (blast furnaces and steel mills). James Ozzello, U.S. Department of State, Trade Agreements Division, has noted that SIC categories 3315, 3316, and 3317 (steel wiredrawing, cold finishing of steel shapes, and steel pipe and tube, respectively) are also included in the voluntary agreement, but data problems excluded them from this exercise. SIC 3312 is the largest of the four categories.

a. 1969 data.

those that compete only partially, both dutiable and otherwise; and those subject to quotas or government-to-government agreements. I assume that decreases in the respective tariffs lead to equal reductions in the prices of competing U.S. goods in the first group, but not in the second.

Table 2 shows major import items subject to quotas or other quantitative restrictions, which in 1971 accounted for $\$ 9.2$ billion in U.S. imports. The remaining task is to divide the $\$ 36.4$ billion in nonquota imports into those that are directly competitive and those that compete only partially with domestic production. The only information readily available on imports that compete closely with domestic production has been provided by the U.S. Bureau of Labor Statistics. ${ }^{62}$ Since I rely on these data, which cover only manufactured imports, costs of the tariff on directly competitive nonmanufactured imports will be understated. As the data shown in Table 3

26. U.S. Bureau of Labor Statistics, "Productivity and Unit Labor Costs in Export and Import-Competing Industries, 1958-68," in United States International Economic Policy in an Interdependent World, Papers Submitted to the Commission on International Trade and Investment Policy (U.S. Government Printing Office, 1971), Vol. 1, pp. 507-33. 


\section{Table 3. Calculation of Competitive U.S. Imports and Duties for 1971 from 1969 Data}

Dollar amounts in millions

\begin{tabular}{lrrc}
\hline \multicolumn{1}{c}{ Line } & Description & Amount & $\begin{array}{c}\text { Percent } \\
\text { of total }\end{array}$ \\
\hline & & & \\
& & & \\
1 & Total imports (c.i.f.) & $\$ 38,314$ & $100.0 \%$ \\
2 & Manufactured & 33,115 & $\ldots$ \\
3 & Directly competitive with U.S. production & \\
4 & Import-competing production in United States & 10,281 & 26.8 \\
5 & Customs duties & 41,500 & $\ldots$ \\
6 & On directly competitive imports & 2,340 & 100.0 \\
7 & On remainder of imports & 814 & 34.8 \\
& & 1,526 & 65.2
\end{tabular}

1971

8 Total imports (f.o.b.)

45,602

100.0

9 Directly competitive with U.S. production ${ }^{8}$

12,220

26.8

10

Quota items

9,235

20.3

11 Other

24,147

53.0

12 Import-competing production in United States

44,862

...

13 Customs duties

14 On directly competitive imports

2,768

100.0

15 On quota items

963

34.8

16 On other imports

Sources: Line 1-International Monetary Fund, International Financial Statistics, Vol. 25 (June 1972), p. 37.

Line 2-Trade Relations Council of the United States, Inc., Employment, Output, and Foreign Trade of U.S. Manufacturing Industries, 1958-69/70 (4th ed.; Washington: TRC, 1972), Vol. 2, p. 793.

Lines 3, 4-Derived by applying data in ibid., Vols. 1 and 2, to four-digit standard industrial classification industries in which imports have very close domestic substitutes, using classification from U.S. Bureau of Labor Statistics, "Productivity and Unit Labor Costs in Export and Import-Competing Industries, 1958-

68," in United States International Economic Policy in an Interdependent World, Papers Submitted to the Commission on International Trade and Investment Policy (U.S. Government Printing Office, July 1971), Vol. 1, App. A.

Line 5-U.S. Tariff Commission, tabulation, "Value of U.S. Imports for Consumption, Duties Collected, and Ratio of Duties to Values, under the Tariff Act of 1930, 1930-71" (March 1972; processed).

Lines 6, 7-Same as Lines 3, 4.

Line 8-International Financial Statistics, Vol. 25 (October 1972), p. 366. Note that the data are on an f.o.b. basis.

Line 9-26.8 percent (from line 3) of line 8.

Lines 10-Table 2.

Line 12-Since data were not yet available on U.S. production competing directly with imports, it is assumed to grow at the same rate as total goods output in the United States. The Economic Report of the President, January 1972 , p. 200, reports that output of total goods increased from $\$ 457.3$ billion in 1969 to $\$ 494.2$ billion in 1971, or an increase of 8.1 percent. Thus line 12 equals 1.081 times line 4.

Line 13-Same as line 5.

Line 14-34.8 percent (from line 6 ) of line 13.

Line 15-Table 2.

Lines 11, 16-Residuals.

Calculations are based on data before rounding.

a. Directly competitive means those manufactured imports that are dutiable and not subject to quotas, and that compete closely with U.S. production. 
indicate, directly competitive imports in 1971 were calculated to be $\$ 12.2$ billion and to compete with $\$ 44.9$ billion in U.S. production. Other imports equaled $\$ 24.1$ billion. Thus, quota items are 20 percent of total imports, directly competitive imports are 27 percent, and the remainder equals 53 percent.

According to the allocation of customs revenue collected in 1971, shown in Table 3, the implied ad valorem tariff rate on all U.S. imports was 6.1 percent: On quota items it was 3.3 percent; on directly competitive imports, 7.9 percent; and on other imports, 6.2 percent.

\section{DIRECTLY COMPETITIVE U.S. IMPORTS}

In order to calculate the welfare effects of the existing tariff structure, values must be assigned to the elasticities of domestic demand, supply, and imports. In Figure 3, these correspond to the elasticities of the domestic demand and supply curves in the region of points $T$ for production and $R$ for consumption. However, equation (1) implies that only two of these three elasticities are independent in the case of imports that are perfectly substitutable with domestic production:

$$
e_{m}=\frac{D}{M}\left(e_{d}-e_{s}\right)+e_{s},
$$

where

$e_{m}=$ the elasticity of demand for imports

$e_{d}=$ the domestic demand elasticity

$e_{s}=$ the domestic supply elasticity

$D=$ the total quantity demanded in the United States (the sum of domestic production plus imports)

$M=$ the quantity of imports consumed.

From Table 3 the ratio of $D$ to $M$ equals $(12.2+44.9) / 12.2$, or $4.67,{ }^{27}$ assuming a domestic price of unity. Since more econometric evidence is available on import price elasticities than on the relevant domestic supply and demand elasticities, I have assumed a value for $e_{m}$ and derived values of $e_{d}$ and $e_{s}$ that satisfy equation (1). The import elasticity, $e_{m}$, is assumed to be

27. For simplicity, in this and similar calculations in this paper, the rounded numbers are given, although the calculations are made from unrounded data. 
-3 in the short run and -8 in the long run. ${ }^{28}$ The short-run elasticity constrains $e_{s}$ to 0.82 if $e_{d}=0$, and $e_{d}$ to -0.64 if $e_{s}=0$. There is evidence that the supply elasticities exceed the demand elasticities (in absolute value) in both the short and the long run. ${ }^{29} \mathrm{I}$ assume that the demand elasticities equal minus one-half the supply elasticities. These assumptions, with equation (1), yield the following pattern of domestic demand and supply elasticities:

\begin{tabular}{lcc}
\multicolumn{1}{c}{ Elasticity } & Short run & Long run \\
Domestic demand, $e_{d}$ & -0.25 & -0.75 \\
Domestic supply, $e_{s}$ & 0.50 & 1.50
\end{tabular}

These elasticities seem low and will mean some underestimate of the welfare costs of U.S. tariffs. For example, on the supply side in the long run, constant costs may be a reasonable assumption, implying that the long-run elasticity of supply would be infinite. ${ }^{30}$ But assuming higher domestic demand and supply elasticities would produce an implausibly high import price elasticity. For simplicity, the discussion in this section assumes that elimination of tariffs on U.S. imports does not raise the world price of U.S. importables. Thus the understatement of the welfare costs using low domestic elasticities is more or less offset by ignoring the terms-of-trade effect on importables. ${ }^{31}$

28. The short-run elasticities are consistent with those found in H. S. Houthakker and Stephen P. Magee, "Income and Price Elasticities in World Trade," Review of Economics and Statistics, Vol. 51 (May 1969), pp. 111-25, while both are somewhat higher than those in John E. Floyd, "The Overvaluation of the Dollar: A Note on the International Price Mechanism," American Economic Review, Vol. 55 (March 1965), pp. 95-107.

29. For example, J. Wemelsfelder, in "The Short-Term Effect of the Lowering of Import Duties in Germany," Economic Journal, Vol. 70 (March 1960), pp. 94-104, found that cuts in West German tariffs in the late 1950s stimulated imports primarily through contraction of production rather than through increases in consumption.

30. See Harry G. Johnson, "Factor Market Distortions and the Shape of the Transformation Curve," Econometrica, Vol. 34 (July 1966), pp. 686-98. Johnson performed simulations on the degree of curvature of the production possibility curve and found that an economy's ability to transform one product into another is extremely high, even under fairly large variations in the parameters of the production functions. A. A. Walters, in "Production and Cost Functions; an Econometric Survey," Econometrica, Vol. 31 (January-April 1963), pp. 1-66, also finds that the evidence for constant returns to scale is very strong. Thus, the assumption of a long-run supply elasticity of 1.5 is too low. The domestic demand elasticities here are also somewhat lower than those estimated by Houthakker and Taylor, Consumer Demand, p. 175.

31. Both estimated and assumed values of the foreign supply elasticity for U.S. imports are high enough in the short run to make this a fairly innocuous assumption. In 
Table 4. Short-run and Long-run Static Effects, from 1971 Base, of Elimination of Tariffs on U.S. Imports with Close Domestic Substitutes

Millions of dollars in annual flows

\begin{tabular}{|c|c|c|c|}
\hline \multirow[b]{2}{*}{ Variable and formula } & \multicolumn{2}{|c|}{$\begin{array}{l}\text { Change in variable } \\
\text { due to price change }\end{array}$} & \multirow[b]{2}{*}{$\begin{array}{c}\text { Analogous } \\
\text { area in Figure } 3\end{array}$} \\
\hline & $\begin{array}{l}\text { Short } \\
\text { run }\end{array}$ & $\begin{array}{l}\text { Long } \\
\text { run }\end{array}$ & \\
\hline Deadweight loss (DWL) elimination & 97 & 291 & $D=D_{1}+D_{2}$ \\
\hline Consumption, $0.5 t^{2} D e_{d}$ & 38 & 114 & $D_{2}$ \\
\hline Production, $-0.5 t^{2} \mathrm{Se}_{\mathrm{s}}$ & 59 & 177 & $D_{1}$ \\
\hline Decrease in domestic production, $-t S\left(1+e_{s}\right)$ & 4,912 & 8,187 & $I+D_{1}+G_{1}$ \\
\hline Redistribution: consumer gain & 4,275 & 4,350 & $I+D+E$ \\
\hline Producers' loss, $t S\left(1-0.5 t e_{s}\right)$ & 3,215 & 3,096 & I \\
\hline $\begin{array}{l}\text { Revenue and DWL to consumers, } \\
0.5 t^{2}\left(-D e_{d}+S e_{s}\right)+t(D-S)\end{array}$ & 1,060 & 1,254 & $D+E$ \\
\hline Increased value of imports & 2,680 & 8,040 & $G_{1}+G_{2}$ \\
\hline Increased consumption, $t D e_{d}$ & 1,042 & 3,126 & $G_{2}$ \\
\hline Reduced production, $t \mathrm{Se}_{\mathrm{s}}$ & 1,638 & 4,914 & $G_{1}$ \\
\hline Revenue loss, $t(D-S)^{\mathfrak{a}}$ & 963 & 963 & $E$ \\
\hline
\end{tabular}

Sources: Derived from indicated formulas, where in the mathematical expressions

$t=$ change in the U.S. price if the quota were eliminated (the ad valorem tariff is 7.9 percent, from text; thus $t=0.079 / 1.079=0.073$ )

$D={ }^{x}$ total demand in the United States (domestic production plus imports) $=\$ 57,082$ million (from Table 3) (note that the $D$ in Figure 3 referred to in the last column stands for deadweight loss, and not total demand.)

$S=$ total supply in the United States $=\$ 44,862$ million (from Table 3)

$e_{d}=$ domestic demand elasticity (short run $=-0.25$; long run $=-0.75$ ) (from text)

$e_{0}=$ domestic supply elasticity (short run $=0.5$; long run $=1.50$ ) (from text)

The calculations were made from data before rounding.

a. The $t$ in this formula differs from the others in the table; it refers to the actual ad valorem tariff rate (7.9 percent), while they refer to the percentage decrease in price ( 7.3 percent).

The formulas for calculating the welfare and structural effects of reducing the 7.9 percent ad valorem tariff on directly competitive imports to zero are shown in Table 4, and described more fully in Johnson's paper. ${ }^{32}$ The table gives the short- and long-run effects of the tariff elimination; these data are shown geometrically in Figure 3, although strictly speaking, the functions should be constant elasticity nonlinear curves in the relevant regions rather than the linear functions of that figure.

Table 4 indicates that the deadweight loss attributable to the current tariff system equals $\$ 97$ million a year in the short run and \$291 million a

the long run, a foreign supply elasticity of infinity is plausible so that the adverse effect on U.S. welfare of a rise in world prices when U.S. tariffs are cut is only a short-run phenomenon.

32. Johnson, "Costs of Protection." 
year in the long run. Most of this distortion is due to misallocation of production. These numbers are underestimates of the social cost of these tariffs, since tariff rates vary around the mean of 7.9 percent, and the welfare loss triangles grow through time; however, they are overestimates in the short run because I have ignored the cost of labor movements. Adjustments for all three of these factors will be performed in a subsequent section. Tariff elimination reduces the value of domestic production by approximately $\$ 5$ billion in the short run and $\$ 8$ billion in the long run, assuming the simple static case of no growth. Elimination benefits consumers of import-competing products by $\$ 4.3$ billion, both in the short and in the long run. Most of this is at the expense of producers of importcompeting production. The value of imports increases by $\$ 2.7$ billion a year in the short run and $\$ 8.0$ billion a year in the long run, mostly through reduced U.S. production rather than increased U.S. consumption. Nearly $\$ 1$ billion in tariff revenue is eliminated, in both the short and the long run.

\section{OTHER U.S. IMPORTS}

To assess the effects of eliminating the 6.2 percent tariff on U.S. imports that are not directly competitive with U.S. production, and not subject to quotas, the analysis assumes an elasticity of import demand of -2 in the short run and of -5 in the long run. With these elasticities, the estimate of the deadweight losses (DWLs) attributable to the tariff is

$$
\begin{aligned}
D W L & =0.5 t^{2} e_{m} V \\
D W L_{s r} & =0.5(0.058)^{2}(2.0)(24,100) \\
& =\$ 81 \text { million } \\
D W L_{l r} & =0.5(0.058)^{2}(5.0)(24,100) \\
& =\$ 202 \text { million, }
\end{aligned}
$$

where $V$ is the value of imports before the tariff cut. The gain to the United States from eliminating this tariff is $\$ 81$ million per year in the short run and $\$ 202$ million per year in the long run. Elimination of this tariff results in a 5.8 percent drop in the price of imported goods; $t=(0.062 / 1.062)=$ 0.058 . Assuming that this reduces the price domestically by 1 percent, ${ }^{33}$ and that domestic supply elasticities are 1.0 in the short run and 3.0 in the long

33. Use of different import price changes and domestic prices changes follows Floyd's technique of handling imports that are imperfectly substitutable with domestic production (see "Overvaluation of the Dollar"). 
Figure 4. Long-run Static Effects, from 1971 Base, of Tariff Elimination on Noncompetitive U.S. Imports

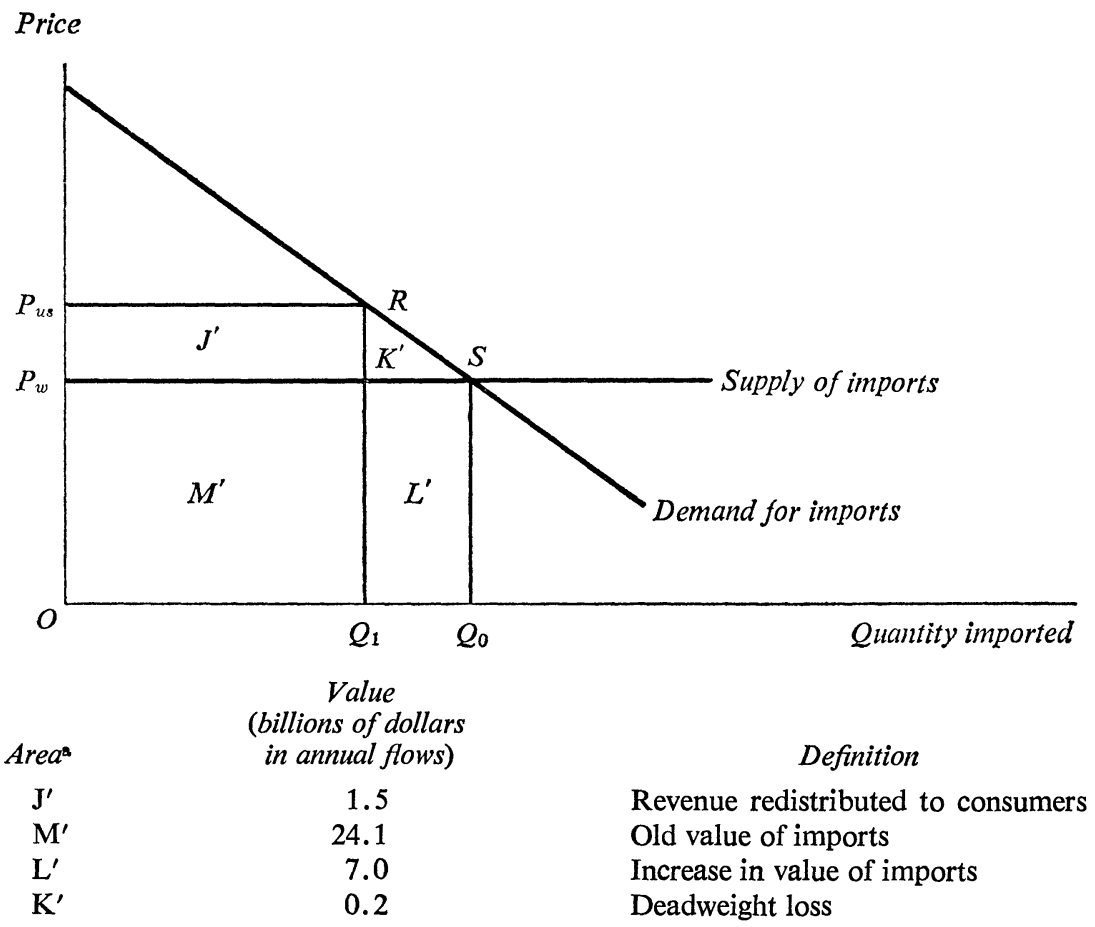

Source: Derived by method discussed in text. a. Not drawn to scale.

run, domestic production declines by $\$ 4.4$ billion and $\$ 8.7$ billion, respectively. The redistribution from producers to consumers is roughly $\$ 2.2$ billion in the short run and $\$ 2.0$ billion in the long run. ${ }^{34}$ This redistribution, plus the revenue and deadweight loss effects, increases the welfare of consumers of these importable products by $\$ 3.8$ billion in the short run and by $\$ 3.7$ billion in the long run. The changes in trade in the long run are shown in Figure 4. The curves are the U.S. import demand curve and the foreign supply curve of goods to the United States. Domestic production and consumption are not shown in Figure 4. Area $K^{\prime}$ is the deadweight loss of the tariff.

34. The domestic production data for this exercise are based on an estimate of $\$ 217$ billion from 1969 data. 


\section{U.S. IMPORTS UNDER QUOTAS}

This section considers the welfare costs associated with quantitative limitations on six major products imported into the United States. Imports of these goods equaled $\$ 9.2$ billion in 1971 (see Table 2). Table 5 shows the values of domestic supply and demand and imports for the six major quota items in 1969. The last column will be combined with equation (1) in some cases to approximate the import price elasticities of demand.

I shall rely in this section on other studies of U.S. import quotas. In some cases these estimate only the consumer cost. This exceeds the social cost to the United States, however, since part of it is a redistribution to U.S. import-competing producers and part of the "tariff-equivalent revenue" is captured by U.S. importers. The actual social cost to the United States equals the deadweight losses plus that part of the tariff-equivalent revenue that is captured by foreign suppliers. The latter portion reflects the possibility that quotas may allow foreign suppliers licensed to sell in the United States to charge more than the world price. The quota operates like a tariff, but the "revenue" is shared by importers and foreign exporters rather than flowing into the U.S. Treasury. Figure 4 can be used to illus-

Table 5. U.S. Domestic Supply, Demand, and Imports of Major Products Subject to Quotas, 1969

Dollar amounts in millions

\begin{tabular}{lrrrr}
\hline Product & $\begin{array}{c}\text { Domestic } \\
\text { supply less } \\
\text { exports }\end{array}$ & Imports & $\begin{array}{c}\text { Domestic } \\
\text { demand }\end{array}$ & $\begin{array}{c}\text { Ratio of } \\
\text { demand to } \\
\text { imports }\end{array}$ \\
\hline Petroleum & $\$ 12,460$ & $\$ 2,480$ & $\$ 14,940$ & 6.02 \\
Steel & 24,300 & 2,009 & 26,310 & 13.10 \\
Textiles, total & 17,597 & 1,632 & 19,229 & 11.78 \\
Man-made & 12,418 & 695 & 13,113 & $\ldots$ \\
Woolen & 1,203 & 410 & 1,613 & $\ldots$ \\
Cotton & 3,976 & 527 & 4,503 & $\ldots$ \\
Sugar & 2,420 & 677 & 3,097 & 4.57 \\
Meat & 9,523 & 558 & 10,081 & 18.07 \\
Dairy & 10,817 & 100 & 10,917 & 109.17 \\
All quota items & $\mathbf{7 7 , 1 1 7}$ & $\mathbf{7 , 4 5 6}$ & $\overline{84,574}$ & 11.34 \\
\hline
\end{tabular}

Source: All data except those for steel and textiles were supplied by Mary Jane Wignot, Office of the Special Representative for Trade Negotiations. The textile data were provided by Emanuel Lipscomb of the U.S. Department of Commerce. The steel data are from the Trade Relations Council of the United States, Inc., and include only SIC 3312 (see the source to Table 2). 
trate these points. If, instead of the tariff, a quota had been used to cut imports from $O Q_{0}$ to $O Q_{1}$, then the quota would have been equivalent to a tariff equal to $P_{u s} P_{w} / O P_{w}$ in that it cut trade by an equivalent amount. ${ }^{35}$ The tariff-equivalent revenue is equal to area $J^{\prime}$. Since there is a gap between internal U.S. prices and world prices, this area will be captured either by U.S. importers or foreign suppliers, or partly by each, depending on the competitive situation in the import market. If it is captured entirely by U.S. importers, the social cost of the quota to the United States equals the deadweight loss triangle, $K^{\prime}$. If it is captured entirely by foreign suppliers, the cost to the United States equals $K^{\prime}+J^{\prime}$. In the third case, where the revenue is shared, the cost is $K^{\prime}+f J^{\prime} ; f$ is the fraction of the tariffequivalent revenue captured by foreigners. The first two situations are simply special cases of the third in which $f=0$ and $f=1$, respectively. Another point is that the observed value of U.S. imports, $M$, will be equal to the area $M^{\prime}+f J^{\prime}$.

In order to convert the published numbers on the consumer cost of quotas into the social costs, I have used the following procedure. As above, $t$ is the change in the U.S. price if the quota were eliminated; the price change can be approximated as

$$
t=C S / D,
$$

where $C S$ is the consumer surplus lost due to the quota and $D$ the value of demand (or consumption), inclusive of $C S .^{36}$ Variable $t$ is then used in the formulas in Table 4 to calculate the deadweight losses.

Calculation of the portion of the tariff-equivalent revenue going to foreigners involves the following variables: $M^{\prime}$ is the value of imports exclusive of the tariff revenue they capture, $f t M^{\prime}$ is the tariff revenue they capture, and the sum of these two items equals observed imports, $M$ :

$$
M=M^{\prime}+f t M^{\prime} .
$$

Thus, $M^{\prime}$ is computed by

$$
M^{\prime}=M /(1+f t)
$$

35. Rachel McCulloch, in "Import Quotas and Resource Allocation" (PhD. dissertation, University of Chicago, 1973), has defined other equivalences in monopolistic cases.

36. This is an exact measure if the domestic demand elasticity equals zero. This calculation of $t$ places no restriction on the foreign supply elasticity of the good to the United States. It is already implicit in the estimates given in the studies surveyed. 
and the tariff-equivalent revenue captured by foreigners, $R F$, in terms of observed imports, $M$, is

$$
R F=\left(\frac{f t}{1+f t}\right) M .
$$

Equation (6) will be used in estimating the tariff-equivalent revenue lost to foreigners under the steel, meat, and dairy quotas.

Petroleum. Bergsten notes that oil quotas raise the domestic price of petroleum by 60 percent. ${ }^{37}$ The Cabinet Task Force on Oil Import Control estimated that the cost to consumers of the oil import quota was $\$ 5$ billion and would increase to $\$ 8$ billion per year by 1980 , involving efficiency costs of $\$ 1.5$ billion to $\$ 2.0$ billion. ${ }^{38}$ Mintz, in commenting on the administration of the oil quota, argues that the loss of tariff-equivalent revenue to foreigners may be small. ${ }^{39}$ Thus, the annual social cost of the oil import quota is assumed here to be $\$ 1.5$ billion. This number is a bit high in the short run, but low in the long run.

Steel. We consider here only standard industrial classification (SIC) 3312, blast furnaces and steel mills, although SIC 3315, 3316, and $3317^{40}$ are also subject to the voluntary limitations. According to Mintz, in December 1968, Japanese and some European steel industries, which accounted for 82 percent of U.S. steel imports, agreed to limit their exports of steel mill products to the United States. James Ozzello ${ }^{41}$ estimates that the

37. See C. Fred Bergsten, "The Cost of Import Restrictions to American Consumers" (American Importers Association, no date; processed), p. 3.

38. Cabinet Task Force on Oil Import Control, The Oil Import Question: A Report on the Relationship of Oil Imports to the National Security (U.S. Government Printing Office, 1970), p. 124. These long-run efficiency costs include only the production deadweight loss; they do not include loss of tariff-equivalent revenue to foreigners or the consumption deadweight loss. See also the study by Kaj Areskoug, "U.S. Oil Import Quotas and National Income," Southern Economic Journal, Vol. 37 (January 1971), pp. 307-17.

39. Mintz, U.S. Import Quotas. tively.

40. Steel wiredrawing, cold finishing of steel shapes, and steel pipe and tube, respec-

41. The estimates made by Ozzello, who is in the Trade Agreements Division of the U.S. Department of State, incorporate the quota, restrictive government procurement policies, and other nontariff barriers. His estimates are not inconsistent with those of C. R. MacPhee in "Nontariff Barriers in International Trade in Steel" (Ph.D. dissertation, Michigan State University, 1970). Restrictive government procurement policies are an important nontariff barrier, both here and abroad; for example, see Norman S. Fieleke, "The Buy-American Policy of the United States Government: Its Balance-ofPayments and Welfare Effects," New England Economic Review (July/August 1969), pp. 2-18. 
ad valorem tariff equivalent of this and other limitations on U.S. imports of SIC 3312 is approximately 17 to 35 percent, and that foreign suppliers usually quote their prices to importers at roughly 5 percent below the U.S. price. With 17 percent taken as a conservative estimate of the cost of the steel limitations, foreigners capture 66 percent of the tariff-equivalent revenue, so that $f=0.66$. Ozzello also believes that the world supply of steel to the United States is highly elastic, so that the fall in the U.S. price of steel with quota elimination would be $t=(0.17 / 1.17)=0.145$.

Equation (2) can be used to calculate the deadweight loss effects of the steel quota. Table 5 and equation (1) imply that the import price elasticity of demand for steel should be high since $D / M=13.1$. If $e_{m}=-10,{ }^{42}$ the deadweight loss is as follows:

$$
\begin{aligned}
D W L & =0.5(0.145)^{2}(10)(2009) \\
& =\$ 211 \text { million. }
\end{aligned}
$$

In addition to this loss, the tariff-equivalent revenue captured by foreigners, from equation (6), is

$$
\begin{aligned}
R F & =\frac{(0.66)(0.145)}{(1+0.66(0.145))} 2009 \\
& =\$ 175 \text { million. }
\end{aligned}
$$

Thus, the total annual cost to the United States of the steel quota on SIC 3312 is $\$ 386$ million.

Textiles. At present, there are two sets of restrictions on U.S. imports of textiles: the long-term agreement on cotton textiles (LTA) and the voluntary agreements with Japan, Taiwan, Korea, and Hong Kong to limit their exports of wool and man-made textiles to the United States..$^{43}$ Because of the nature of these agreements, most of the tariff-equivalent revenue is probably captured by foreigners. Mintz found that the biggest social cost would be in the area of woolen and man-made textiles. She hesitates to place a precise national cost on the textile limitations because the data are inadequate, but takes $\$ 1.25$ billion per year as a best guess (roughly half of her estimate of the consumer cost). She estimates that this number will double between 1972 and 1976. To be conservative, I shall use $\$ 1.25$ billion in this exercise.

42. This value equals the "high" value used in Baldwin and Mutti, "Policy Problems," App. 1.

43. See Mintz, U.S. Import Quotas, for a discussion of the history and the administration of these agreements. 
Sugar. Mintz has calculated the consumption deadweight loss of the sugar quota at $\$ 10$ million to $\$ 25$ million per year and the production deadweight loss at $\$ 79$ million to $\$ 110$ million per year, yielding a total annual deadweight loss of $\$ 89$ million to $\$ 135$ million. She estimates the tariffequivalent revenue paid to foreigners at $\$ 265$ million to $\$ 317$ million. Summing the means of these ranges gives an annual average loss due to the sugar quota of $\$ 403$ million.

Meat and dairy products. Bergsten has noted that the annual consumption costs of the meat import quotas is $\$ 350$ million..$^{44}$ From equation (3), the ad valorem tariff equivalent is 3.5 percent, and the price decrease with the elimination of the quota is 3.38 percent. $^{45} \mathrm{I}$ assume arbitrarily that foreigners capture half the tariff-equivalent revenue, and that the price elasticity of demand for meat imports is -10 . This yields a deadweight loss of $\$ 3.2$ million and tariff-equivalent revenue lost to foreigners of $\$ 9.3$ million. The total annual social cost is $\$ 12.5$ million. ${ }^{46}$

Bergsten estimates that approximately $\$ 500$ million is paid annually by consumers of dairy products because of the quota. ${ }^{47}$ From equation (3), the tariff equivalent is 4.6 percent, implying that $t=0.044$. Assuming, arbitrarily, that the foreign supply is infinitely elastic and that the U.S. import price elasticity is -20 (see the large number for $D / M$ in Table 5), the deadweight loss is $\$ 1.9$ million and the revenue captured by foreigners equals $\$ 2.2$ million, or a total social cost of $\$ 4.1$ million a year.

Total quotas. The sum of the annual long-run costs to the United States of the six quantitative import limitations considered in this section is $\$ 3,555$ million. Assuming that the textile loss is equally divided between deadweight loss and tariff-equivalent revenue lost to foreigners implies that $\$ 2.4$ billion of the $\$ 3.6$ billion annual cost of all quotas is deadweight loss and $\$ 1.2$ billion is tariff-equivalent revenue lost to foreigners. While

44. Bergsten, "Cost of Restrictions," p. 4.

45. Geoffrey H. Jackson, "The Impact of Eliminating the Quota on U.S. Imports of Beef," Agricultural Economics Research Paper 338 (Cornell University, Department of Agricultural Economics, January 1972; processed), estimates that eliminating the beef quota would result in a 2.6 percent decline in the U.S. price in 1975.

46. Bergsten notes that the voluntary restraints by the major foreign suppliers of fresh and frozen meat hit low-income families relatively severely since most meat imports are used in the manufacture of low-cost items such as frankfurters and hamburgers ("Cost of Restrictions," p. 4). President Nixon liberalized these controls somewhat in 1970 because of these adverse price effects. This exercise ignores the recent suspension of the beef quota.

47. Ibid. 
the costs of quotas seem high relative to the previous tariff estimates, two facts should be kept in mind. First, the deadweight losses of the restrictions increase with the square of the ad valorem equivalent tariff rate. The relatively high rates on petroleum, steel, and textiles generate large losses relative to the size of imports. Second, loss of tariff-equivalent revenue accounted for almost a third of the U.S. social loss due to quotas. Tariffs, of course, do not impose this cost.

\section{COSTS OF EXISTING RESTRICTIONS ON U.S. EXPORTS}

What would be the benefits to the United States of removal of foreign barriers to its exports? In the import section we assumed for simplicity that the United States was a price taker in world markets; that is, tariff reductions in the United States would not increase world prices noticeably. However, since countries tend to specialize more in production than consumption, foreign demand for U.S. exports cannot be taken as perfectly elastic. Thus I assume that the short-run elasticity of demand for U.S. manufactured exports is -1.0 and that the long-run elasticity is $-4.5 .48$

U.S. exports can be broken into three groups: manufactured goods in which exports are an important part of domestic production, agricultural exports, and all other exports. In the last category exports are quite small relative to total production and the export supply elasticity is likely to be extremely high, so that foreign tariff cuts will not significantly affect the price of these goods to producers or consumers in the United States. Hence, the welfare effects are negligible and the category can be ignored here. In the first case, U.S. industries in which manufactured exports were a substantial portion of sales exported an estimated $\$ 13.5$ billion worth of goods and sold $\$ 77.3$ billion in the United States in 1971.49 This leaves

48. In Magee, "Tariffs and U.S. Trade," the direct price elasticities of demand used for U.S. exports in a fifteen-region model were -2.7 , while the cross-price elasticities with respect to other suppliers to each market averaged 1.7 . Therefore, the elasticity appropriate for foreign tariff elimination on both U.S. and foreign exports is the difference between these two elasticities, or -1.0 in the short run. The assumption that the long-run demand elasticity equals -4.5 is arbitrary.

49. BLS data indicate that in 1967, U.S. manufacturing industries whose exports accounted for a substantial portion of total sales exported $\$ 9.49$ billion; the value of total shipments in these industries in 1967 was $\$ 71.84$ billion. The included industries are those in which exports "represented 10 percent or more of the value of domestic output ... [or] represented at least 6 percent of domestic output and had a value [of exports] 
$\$ 22.3$ billion in "other" U.S. exports (which are not examined here), and $\$ 7.8$ billion in agricultural exports, giving a total export level of $\$ 43.6$ billion. ${ }^{50}$

Manufactured exports. Considering first the $\$ 13.5$ billion in 1971 U.S. manufactured exports that are an important part of total production in their respective industries, I assume domestic supply and demand elasticities for these goods that give plausible values of the U.S. export supply elasticities. It turns out that the domestic elasticities given in the informal table on page 665 for directly competitive U.S. imports give reasonable values for the U.S. export supply elasticities, $s_{x}$, using formula (7):

$$
\begin{gathered}
s_{x}=\frac{S}{X}\left(e_{s}-e_{d}\right)+e_{d}, \\
\text { short-run } s_{x}=6.7[0.5-(-0.25)]+(-0.25)=4.8, \\
\text { long-run } s_{x}=6.7[1.5-(-0.75)]+(-0.75)=14.4,
\end{gathered}
$$

where $S$ is the value of the supply of exportable products produced in the United States in 1971 and equals the sum of the amount sold in the domestic market, $D$, plus the amount exported, $X$. In this case, $S=(D+X)=$ $(77.3+13.5)=\$ 90.8$ billion in 1971 , and $S / X=6.7$, giving a short-run supply elasticity of 4.8 and a long-run elasticity of $14.4 . .^{51}$ The supply and demand elasticities for U.S. exports are as follows:

Elasticity

Foreign demand, $d_{x}$

U.S. export supply, $s_{x}$
Short-run

$-1.0$
Long-run

$-4.5$

14.4

of at least \$150 million" (BLS, "Productivity and Unit Labor Costs," pp. 507-08). From subtraction, $\$ 62.35$ billion is the value of output in these industries that was sold in the United States. The $\$ 9.49$ billion in exports was 31 percent of total nonmilitary merchandise exports of $\$ 30.6$ billion in 1967. The growth factor for 1967-71 of 24 percent on domestic goods output (Economic Report of the President, January 1972, p. 200) implies that domestic sales would have been $\$ 77.3$ billion in 1971. Taking 31 percent of total merchandise exports in 1971 ( $\$ 43.6$ billion) equals $\$ 13.5$ billion for the exports in question.

50. Jack J. Bame, "Balance of Payments Developments: Fourth Quarter and Year 1971," Survey of Current Business, Vol. 52 (March 1972), p. 39.

51. In Stephen P. Magee, "A Theoretical and Empirical Examination of Supply and Demand Relationships in U.S. International Trade," A Study for the Council of Economic Advisers (October 1970), the short-run (annual data, unlagged) U.S. export supply elasticity was estimated to be in the region of 10 . However, this is for total exports and includes the high-elasticity items in which exports are a small proportion of domestic sales. Thus, the short-run elasticity of 4.8 used here is not unreasonable for the exports under consideration. 
These elasticities can be used with the foreign tariff rates to calculate the change in the price of exportables in the United States if foreign tariffs were eliminated. The average ad valorem tariff rate on dutiable U.S. exports to the European Economic Community, the five largest countries of the European Free Trade Association (EFTA), Canada, and Japan is 11.3 percent, using 1968 weights. ${ }^{52}$ The effective tariff on the price including tariff is thus $0.113 / 1.113$, or 10.1 percent, which is denoted as $\% \Delta T$. The percentage change in the dollar price of U.S. exports, $\% \Delta P X$, is shown in equation (8):

$$
\%_{0} \Delta P X=\left(\frac{d_{x}}{d_{x}-s_{x}}\right) \% \Delta T .
$$

Substituting the values of the supply and demand elasticities into equation (8) yields the following percentage changes in the price of exportables in the United States:

$$
\begin{array}{ll}
\text { short-run } & \% \Delta P X=\left(\frac{-1.0}{-1.0-4.8}\right) 10.1=1.75 \\
\text { long-run } & \% \Delta P X=\left(\frac{-4.5}{-4.5-14.4}\right) 10.1=2.40 .
\end{array}
$$

In the short run, foreign tariff elimination raises U.S. home prices of exportables by 1.75 percent, while the long-run prices of U.S. exportables rise by 2.4 percent. Foreign tariff reductions lower the delivered prices of U.S. goods abroad but raise the prices received by U.S. exporters as the increase in the foreign demand causes U.S. producers to move up their export supply function.

The percentage changes in the price of U.S. exports just calculated can be treated as the tariff changes were in the section on imports. Thus, $t=$ 0.0175 in the short run and $t=0.024$ in the long run. The short- and longrun effects of foreign tariff elimination on U.S. exportables are shown in Table 6. The long-run results in that table are shown in Figure 5. I assume, as before, that $O P_{u s}=1$. The total gain in welfare in the United States as a result of foreign tariff elimination is equal to the sum of the deadweight loss triangles plus the amount of tariff revenue that was formerly collected in foreign customs but is now captured by U.S. exporters. These gains are the sum of areas $D$ and $E$ and equal $\$ 246$ million in the short run and $\$ 380$ million per year in the long run.

52. These numbers are derivable from GATT, Basic Documentation. See Magee, "Tariffs and U.S. Trade," for these calculations. 
Table 6 also shows that the value of the domestic production of exportables increases by $\$ 2.4$ billion per year in the short run and $\$ 5.6$ billion in the long run. Because the U.S. price of exportables rises, U.S. consumers of exportables are worse off: In the short run the consumer loss is $\$ 1.4$ billion and in the long run it equals $\$ 1.8$ billion. The increase in producers' surplus equals the sum of the redistribution effect from U.S. consumers plus elimination of the deadweight losses plus area $E$, which is a portion of revenue formerly collected abroad on U.S. exports. The value of U.S. exports increases by $\$ 1.4$ billion in the short run and $\$ 5.1$ billion in the long run, owing to three factors: the greater supply of exportables in the United States, the reduced demand for exportable products in the United States as a result of their increase in price, and the revenue formerly paid to foreign customs plus the deadweight losses.

Agricultural exports. The gains from removal of restrictions on U.S. agricultural products are potentially large. Even though only about 20 percent of U.S. exports are agricultural products, the nation does have a comparative advantage in a number of products that are subject to heavy protection abroad and restricted production at home. In 1969, exports provided 14 percent of farm cash receipts; however, agricultural production was 7.3 percent below potential and exports could be increased by 77 percent, according to Upchurch, if idle resources were utilized. ${ }^{53}$ In contrast with the usual case, an expansion of U.S. agricultural exports, even without an increase in their price, would still mean a U.S. welfare gain since domestic programs designed to keep farm resources idle in order to maintain farm income could be dismantled. The opportunity costs are near zero for the resources-namely, land-that could be used to expand U.S. agricultural exports; every dollar of additional exports thus represents an addition to U.S. welfare. Lawrence B. Krause, in a study under way at this writing, and D. Gale Johnson agree that the elimination of barriers against U.S. agricultural exports in Western Europe and Japan could lead to an annual expansion of at least $\$ 3$ billion to $\$ 5$ billion in U.S. exports and welfare. ${ }^{54}$ In what follows, I assume a short-run gain of $\$ 3$ billion and a

53. M. L. Upchurch, "Competitive Position of U.S. Agriculture," in United States International Economic Policy in an Interdependent World, Vol. 1, pp. 836-38.

54. D. Gale Johnson, "The Impact of Freer Trade on North American Agriculture" (paper delivered at the joint session of the American Economic Association and the American Agricultural Economics Association, Toronto, December 29, 1972). 
Table 6. Short-run and Long-run Static Effects, from 1971 Base, of Elimination of Tariffs on Major U.S. Manufactured Exports

Millions of dollars, annual flows

\begin{tabular}{|c|c|c|c|}
\hline \multirow[b]{2}{*}{ Variable and formula } & \multicolumn{2}{|c|}{$\begin{array}{c}\text { Change in variable } \\
\text { due to price } \\
\text { change }\end{array}$} & \multirow[b]{2}{*}{$\begin{array}{l}\text { Analogous } \\
\text { area in Figure } 5\end{array}$} \\
\hline & $\begin{array}{l}\text { Short } \\
\text { run }\end{array}$ & $\begin{array}{l}\text { Long } \\
\text { run }\end{array}$ & \\
\hline Deadweight loss ( $D W L)$ elimination & 10 & 56 & $D=D_{1}+D_{2}$ \\
\hline Consumption, $-0.5 t^{2} D e_{d}$ & 3 & 17 & $D_{2}$ \\
\hline Production, $0.5 t^{2} \mathrm{Se}_{\mathrm{s}}$ & 7 & 39 & $D_{1}$ \\
\hline Increased value of domestic production & 2,404 & 5,599 & $I+2 D_{2}+E+G_{1}+2 D_{1}$ \\
\hline $\begin{array}{l}\text { Redistribution: consumer loss, } \\
\quad t D-0.5 t^{2} D e_{d}\end{array}$ & 1,350 & 1,872 & $I$ \\
\hline $\begin{array}{l}\text { Redistribution: producer gain, } \\
\qquad t S+0.5 t^{2} S e_{s}\end{array}$ & 1,596 & 2,252 & $I+D+E$ \\
\hline Increased value of exports & 1,388 & 5,096 & $G_{2}+2 D_{2}+E+2 D_{1}+G_{1}$ \\
\hline Increased supply, $t S e_{s}(1+t)$ & 808 & 3,347 & $G_{1}+2 D_{1}$ \\
\hline Reduced demand, $t D e_{d}(1+t)$ & 344 & 1,425 & $G_{2}+2 D_{2}$ \\
\hline Revenue, $t(S-D)$ & 236 & 324 & $E$ \\
\hline Total U.S. welfare gain & 246 & 380 & $D+E$ \\
\hline
\end{tabular}

Sources: Derived from the indicated formulas, where all the symbols and the values of $e_{d}$ and $e_{8}$ are as defined in Table 4, and (from text) $D=\$ 77.3$ billion, $S=\$ 90.8$ billion, and $t=0.0175$ and 0.024 for the short and long run, respectively. The calculations were made from data before rounding.

long-run gain of $\$ 5$ billion per year. Thus, the biggest gains to free trade for U.S. exports are in the agricultural area.

\section{ADJUSTMENT FOR TRANSITION COSTS, AGGREGATION BIAS, AND GROWTH}

Transition costs. Previous sections have established that the gains from elimination of trade restrictions are small in the short run but build up as the economy adjusts to free trade. However, the costs involved in moving resources from one sector of the economy to another must be considered. Trade liberalization moves resources out of import-competing activities and into nontradable and export activities. Since this analysis takes a long-run view of the efficiency question, I measure these resource shifts at full employment. The nation has been both above and below full employment in the past decade and, in any case, these calculations should not include the cost of failure of aggregate demand policy, in either direction. 
Figure 5. Long-run Static Effects from 1971 Base of Elimination of Tariffs on U.S. Major Manufactured Exports

\section{Price}

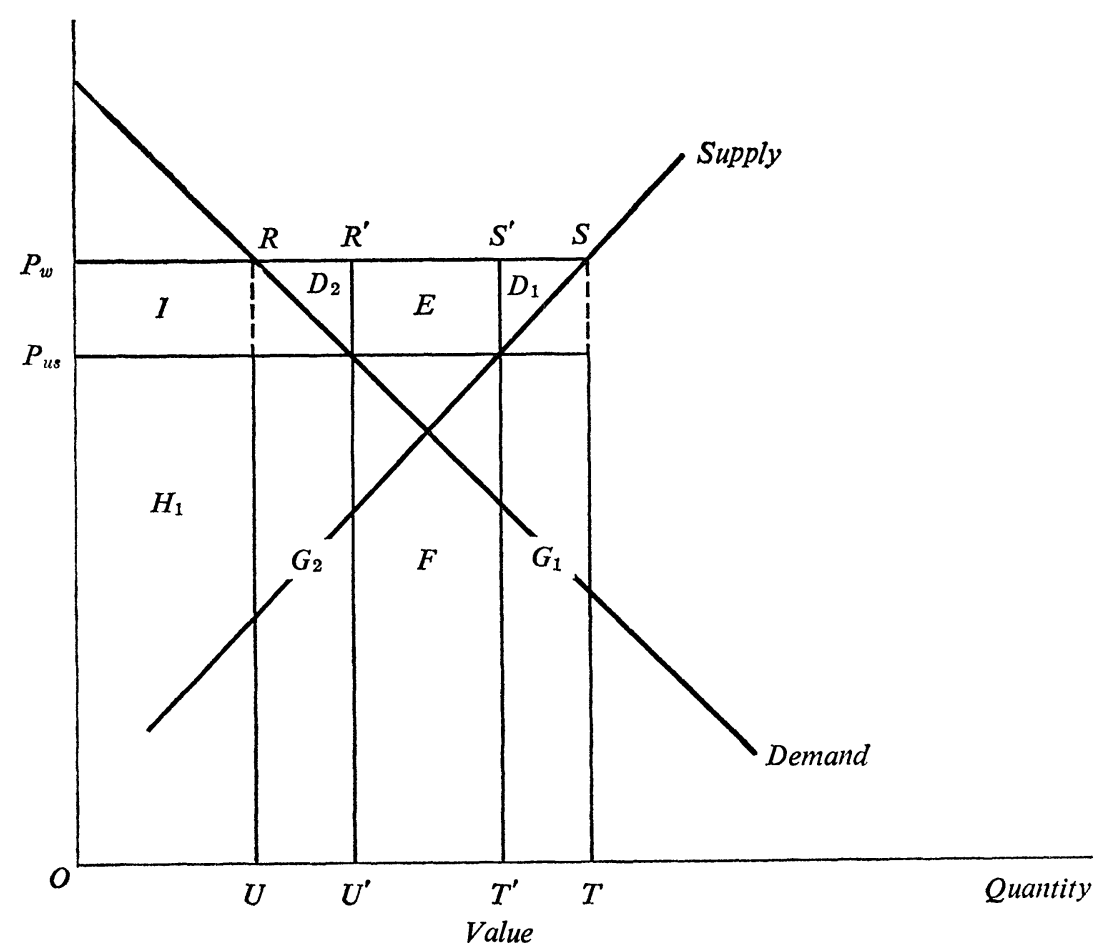

\begin{tabular}{|c|c|c|}
\hline Area $^{\mathrm{a}}$ & $\begin{array}{l}\text { (billions of dollars } \\
\text { annual flows) }\end{array}$ & Definition \\
\hline$I$ & 1.9 & $\begin{array}{l}\text { Redistribution from consumers to pro- } \\
\text { ducers }\end{array}$ \\
\hline$H_{1}+G_{2}$ & 77.3 & Old level of domestic consumption \\
\hline$D=D_{1}+D_{2}$ & 0.1 & Deadweight loss \\
\hline$E$ & 0.3 & Old value of foreign tariff revenue \\
\hline$G_{2}+2 D_{1}+E+2 D_{2}+G_{1}$ & 5.1 & Change in the value of exports \\
\hline$F$ & 13.5 & Old value of exports \\
\hline$R S T U$ & 18.6 & New value of exports \\
\hline$G_{1}$ & 3.3 & $\begin{array}{l}\text { Increased supply of exports (one of the } \\
\text { components in change in value of ex- } \\
\text { ports) }\end{array}$ \\
\hline$G_{2}$ & 1.4 & $\begin{array}{l}\text { Reduced demand for exports (one of } \\
\text { the components in change in value } \\
\text { of exports) }\end{array}$ \\
\hline
\end{tabular}

Sources: Same as Table 6.

a. Not drawn_to scale. 
Moving resources is not frictionless, and the need here is to measure the cost of moving below potential gross national product (or inside the economy's production possibility curve) in the transition period after trade liberalization. There is no clean measure of this social cost: As a proxy, I follow Baldwin and Mutti ${ }^{55}$ and use the income (and presumably the production) lost by labor as it moves from one sector to another. For simplicity, I ignore the short-run output response, calculate the long-run output change and the implied change in employment, multiply this by a wage rate and an assumed duration of unemployment, and spread this loss equally over the five-year period that I assume industries require to adjust to changes in trade barriers and reach a new long-run equilibrium.

The results for both U.S. imports and U.S. exports are shown in Table 7. The notes to the table explain the mechanics of the calculations. The purpose of the table is not a precise gauge but a crude measure of the economic cost of moving resources; among its flaws are the failure to examine foreign nontariff barriers and the guesswork that underlies many of the estimates. Because people must move from one job to another, expanding exports entails costs just as contracting imports does, but the costs are lower because less time is lost, among other things. To the extent that resources leaving import-competing industries are absorbed into export industries, the transition costs are overstated. However, the skill requirements in the two generally differ sufficiently that this overstatement will be small. The last three rows of the table give the present value of the job-change costs for the assumed five-year period over which they take place.

Aggregation bias. In addition to the costs of moving resources, correction must be made for certain aggregation biases in the estimates of the deadweight losses imposed by U.S. and foreign tariffs. Tables 4 and 6 indicate that, for fixed values of the relevant elasticity and the base, the social cost of a tariff is a function of the square of the tariff rate. The deadweight loss calculations would not be subject to aggregation bias if each of the component tariff rates were equal. However, if they are not (as is the case), aggregation bias exists, and it increases with the variance of the tariff rates around the mean. To correct this situation, I have constructed the "root mean-squared tariff," $t_{r}$, which, at the aggregate level, yields a bias-free estimate of the welfare loss of the tariff structure:

$$
t_{r}=\sqrt{\sum_{i} a_{i} t_{i}^{2}}
$$

55. "Policy Problems." 
where $t_{i}$ is the middle of tariff range $i$ (for example, $t_{i}=0.015$ in the range between $t=0.01$ and $t=0.02$ ) and $a_{i}$ is the share of total trade with tariff rates falling in range $i$. The average tariff rate used in the earlier calculations, $t_{a}$, is

$$
t_{a}=\sum a_{i} t_{i}
$$

The proposition that $t_{r}>t_{a}$ can be illustrated in the following two cases. Both deal with two products, with equal weights in imports $\left(a_{1}=a_{2}=\right.$ 0.5 ) and the same mean total tariff rate; in case $A, t_{1}=10$ and $t_{2}=10$, while in case $B, t_{1}=0$ and $t_{2}=20$. The subscripts indicate the product number. According to equations (2) and (9), the true welfare costs of case $B$ are greater than those of case $A$ :

Case $A \quad D W L=0.5 e_{m} V\left(0.5 \times 0.1^{2}+0.5 \times 0.1^{2}\right)=0.01\left(0.5 e_{m} V\right)$

Case $B \quad D W L=0.5 e_{m} V\left(0.5 \times 0^{2}+0.5 \times 0.2^{2}\right)=0.02\left(0.5 e_{m} V\right)$.

The deadweight loss estimates for imports in Table 4 (\$97 million and \$291 million) and equation (2) (\$81 million and \$202 million) and for exports in Table 6 ( $\$ 10$ million and $\$ 56$ million) must be adjusted upward by a correction factor, $C$ :

$$
C=\frac{t_{r}^{2}}{t_{a}^{2}}
$$

Using tariff dispersion data from the GATT study, ${ }^{56} \mathrm{I}$ estimate that $t_{r}=0.100$ and $t_{a}=0.059$ for total (not just dutiable) U.S. imports, so that $C=2.87$. Multiplying this factor times the deadweight losses of Table 4 gives the following estimates, which are free of aggregation bias:

$$
\begin{array}{cc}
\text { Short-run } & \text { Long-run } \\
\text { deadweight losses } & \text { deadweight losses } \\
\text { (millions of dollars) } & \text { (millions of dollars) }
\end{array}
$$

$\begin{array}{llr}\text { Directly competitive } & 278 & 835 \\ \text { Other } & 232 & 580 \\ & 510 & 1,415\end{array}$

As a proxy for the calculation of $t_{r}$ for U.S. exports, I use data on dispersion for "world tariffs," which, in addition to imports into the United States, includes those of the EEC and nine other major developed countries. The results yield $t_{r}=0.083$ and $t_{a}=0.051$, so that $C=2.65$. Based on this 


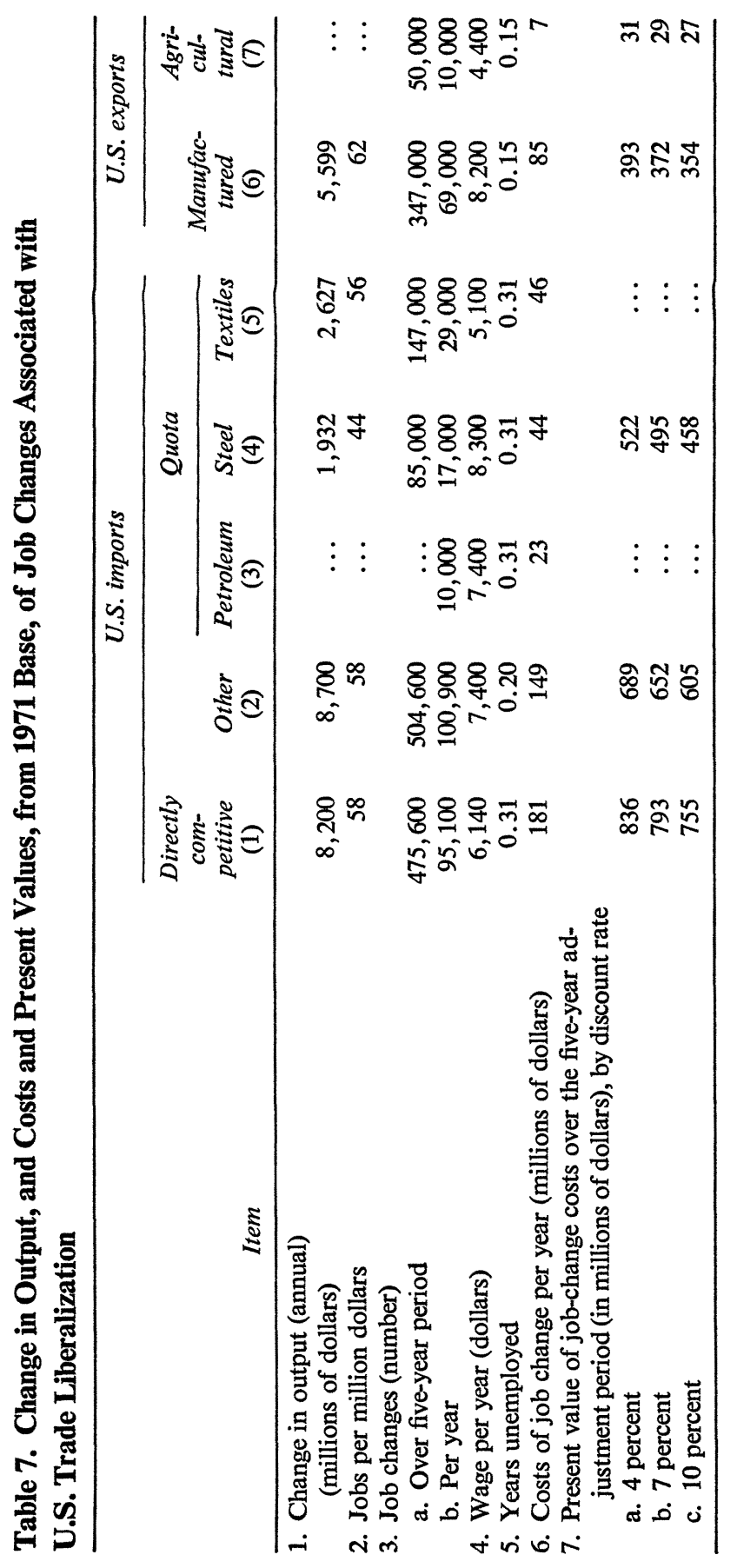




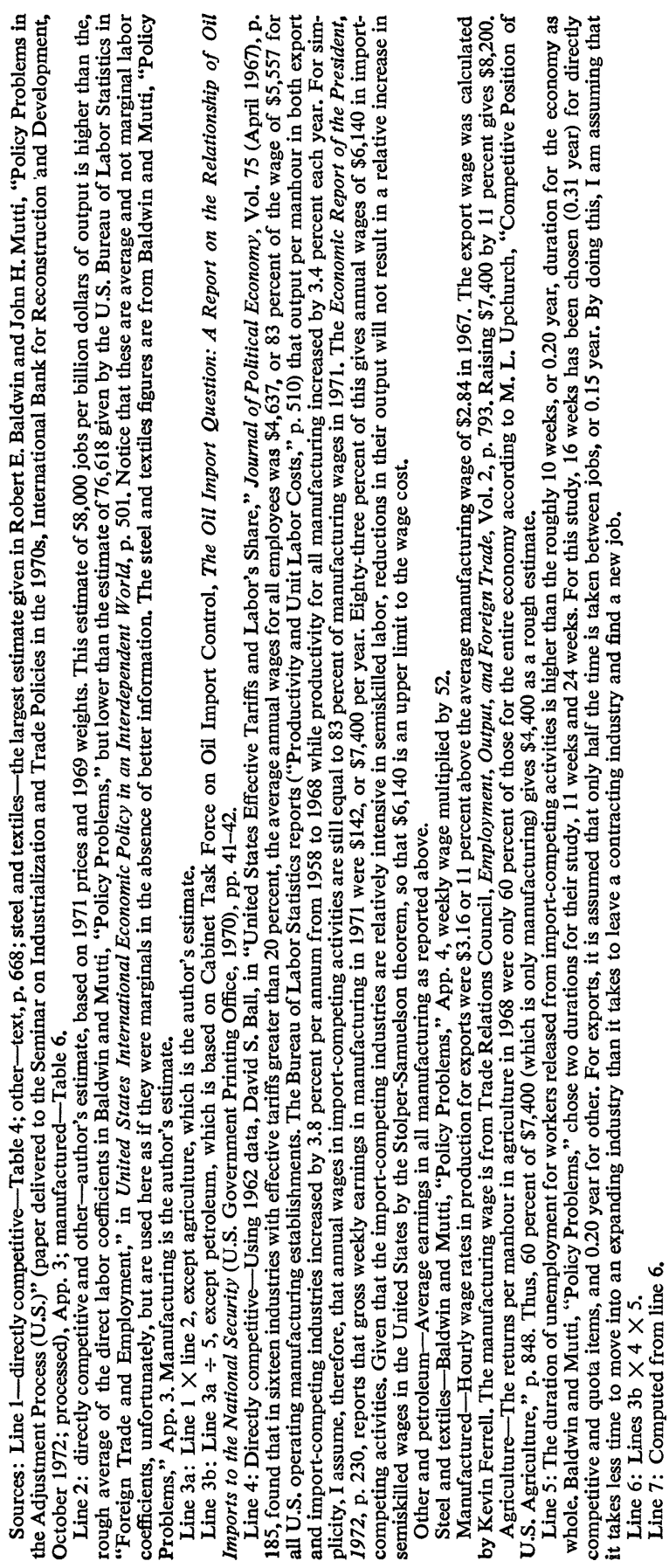


factor times the deadweight losses in Table 6, and the revenue components, $\$ 262$ million is the short-run and $\$ 472$ million the actual long-run annual costs of foreign tariffs on U.S. exports of manufactures. The following discussion relies on these corrected figures. Three aspects of these adjustments should be noted. First, the large sizes of the correction factors indicate that the tariff distributions are considerably skewed. Second, the larger adjustment factor for U.S. imports reflects the "tariff disparities" issue for which the United States had to make concessions in the Kennedy Round. Third, the tariff distribution data were not available separately for the two categories of imports used here. Thus, a single correction factor calculated from all manufactured trade was applied to both import categories.

Growth. Thus far, the analysis has been static. The only changes in the flows through time involved movement from short-run to long-run positions. If in fact domestic supply and demand grow at an annual rate, $g$, the estimate of deadweight loss (see Table 4) for consumption in year $i$ can be written

$$
D W L_{i}=0.5 t^{2} e_{d} D_{0}(1+g)^{i},
$$

where $g$ is the proportional annual growth rate and $D_{0}$ is the initial quantity of the importable demanded. The present value of the $D W L$ in year $i$ can be written

$$
\begin{aligned}
P V_{i} & =\frac{0.5 t^{2} e_{d} D_{0}(1+g)^{i}}{(1+r)^{i}} \\
& =0.5 t^{2} e_{d} D_{0}(1+d)^{-i},
\end{aligned}
$$

where $d$ is the discount factor, incorporating both growth and the rate of capitalization, $r$, and approximately equal to $r-g$. I assume that the appropriate rate of social capitalization, $r$, is somewhere between 6 and 12 percent. The real growth rate for the economy as a whole and for the consumption of items directly competitive with imports can be approximated at 4 percent. Thus, assuming $r=0.08$ and $g=0.04$ gives $d=0.04$, that is, a discount factor of 4 percent.

The present value of the consumption deadweight loss, including growth, is the sum of all future deadweight losses discounted at 4 percent. Table 8 gives the costs of U.S. tariffs and quotas at alternative discount rates of 4 percent, 7 percent, and 10 percent. While 4 percent is probably the most plausible estimate, the 7 and 10 percent rates were included to permit the 


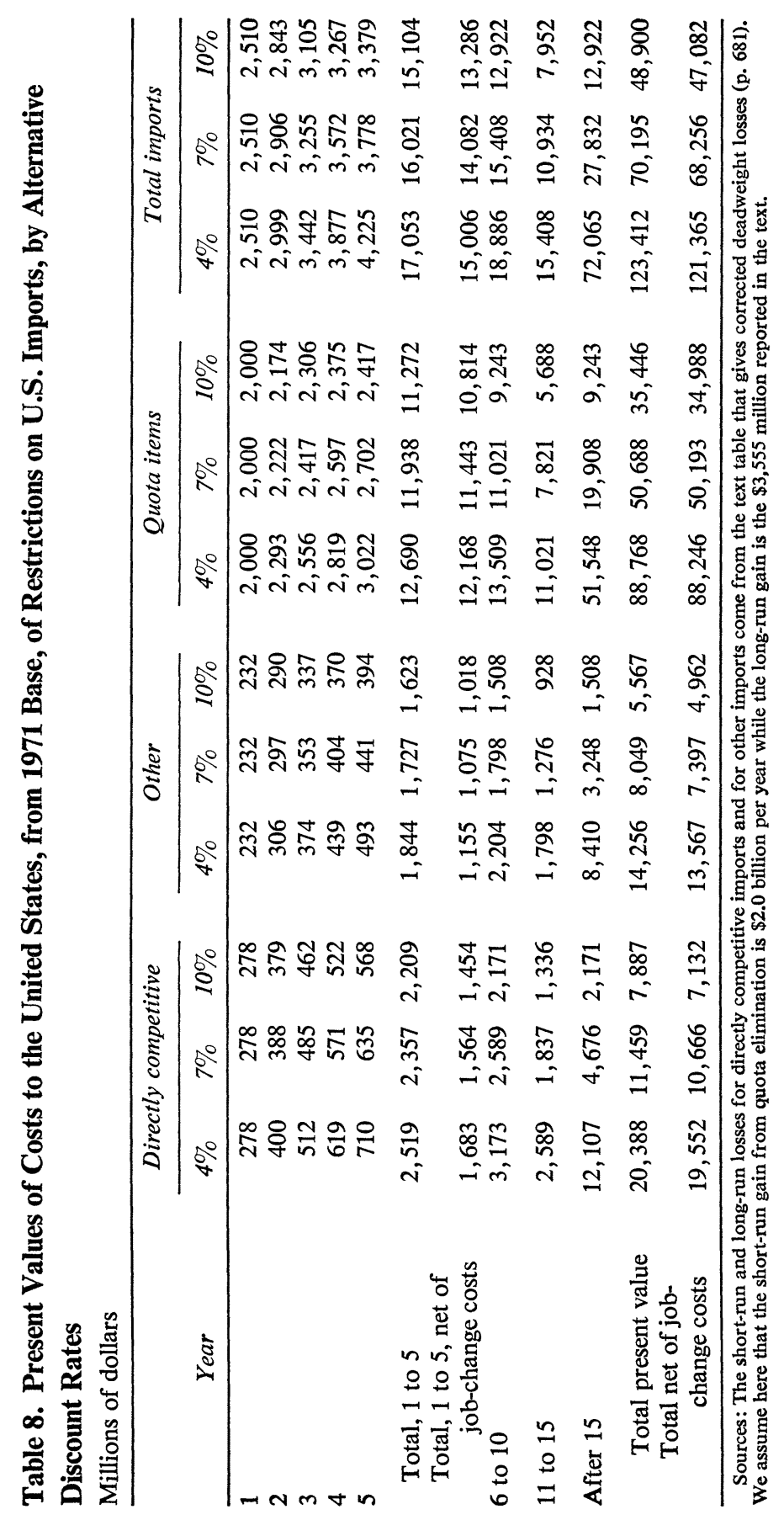


discounting in the absence of growth or alternative gaps between $r$ and $g$. The next to last line of Table 8 gives the total present cost of each restriction and the previous three lines provide some feel for the time path of the total present value. For example, 59 percent $(12.1 / 20.4)$ of the gain from eliminating the tariff on directly competitive imports comes after year 15 when a 4 percent discount is used. The components of the present values are broken into four time periods. If one believed that Mundellian-type factor movements (see note 21 and the related discussion) would eliminate trade after fifteen years, the fourth period should be ignored.

The income losses due to job changes in the first five years are subtracted from the gains, and the results shown in the line labeled, "total, 1 to 5, net of job-change costs." For nonquota imports in the first five years, the costs of job changes absorb nearly a third of the short-run gain from reduction in the trade barrier. In the long run, the gains from free trade are more important. Since most political horizons are rather short, this helps explain part of the political resistance to freer trade. Table 9 gives the same data for U.S. exports, and shows that the gains to the United States from free world trade for agricultural products dominate. Remember, however, that no estimates are made in this paper of the costs to the United States of foreign nonagricultural quotas and nontariff barriers. Also, since there is no reason to believe that trade liberalization will cause changes in the U.S. trade balance, no calculations are made here for the effects of currency realignments induced by trade liberalization.

\section{Moving to More Restricted Trade}

\section{CUTTING TRADE TO 1965-69 LEVELS}

An extreme protectionist proposal is contained in Title III of the BurkeHartke bill to amend the tariff and trade laws, introduced in the Congress in September 1971. They provided that the quantity of U.S. imports in the first year (1972), both by product categories and by country, should not exceed the average quantities imported during the calendar years 1965-69. The product categories were to be defined by a proposed United States Foreign Trade and Investment Commission (FTIC) on the basis of the fivedigit and seven-digit classifications used in the Tariff Schedules of the United States, Annotated. Products were to be grouped so as not to "ad- 


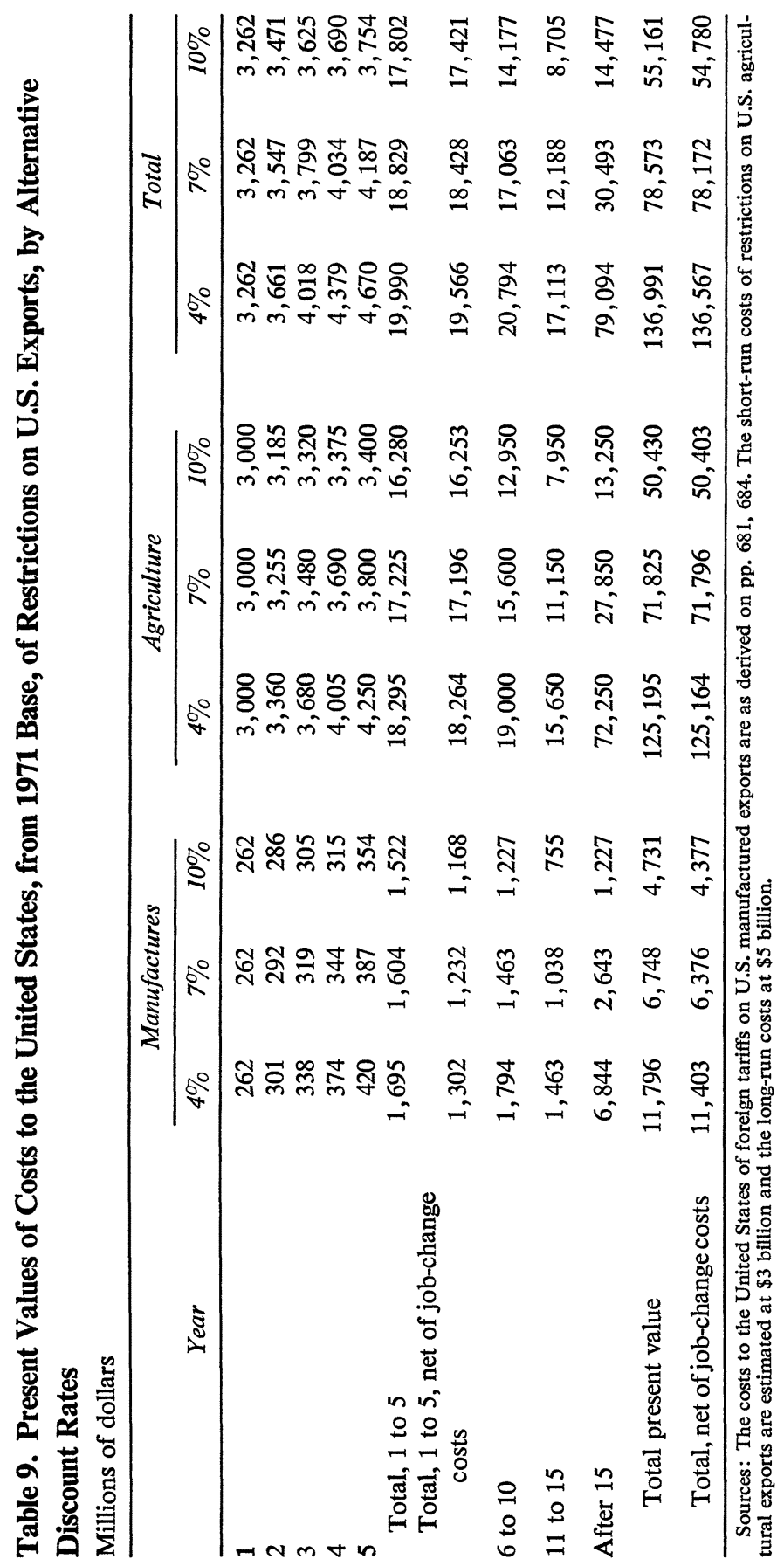


versely affect the assembly or production of any item or component in the United States." 57

The bills provided that after 1972 the quotas could be increased but the ratio of imports to domestic production was to remain at the 1965-69 levels. The FTIC could decrease the level of any quota if it found that imports were "inhibiting the production of any manufactured product," a particularly striking provision since the whole purpose of competition, including foreign competition, is to disrupt inefficient production. Conversely, the FTIC could relax the quotas on inputs and intermediate products that would "inhibit the production" of U.S. goods. If in any year, the FTIC determined that a foreign country was unlikely to make full use of its quota, the bill provided that "it shall so inform the President, and shall distribute the quota among new or existing suppliers as the President may direct." 59

The only imports exempt under Title III are goods in which the FTIC decides that (1) quantitative limitations on U.S. imports are already effective (through voluntary bilateral or multilateral government-to-government agreement or legal controls); (2) "failure to import the goods would cause long-term disruption of United States markets"; and (3) "the domestic industry producing competing goods has consistently failed to make technological innovations required to remain competitive with foreign producers." 60

What would be the effects of the quantitative rollbacks in trade from 1971 to the 1965-69 levels (1972 data were not available at the time of this writing)? Table 2 listed those items that would be excepted from the controls because of existing quotas or government-to-government agreements. Excluding steel, these imports amount to approximately $\$ 7.2$ billion (based on 1971 data). ${ }^{61}$ If the FTIC granted exemptions to avoid long-term disruption of U.S. markets for goods totally without domestic substitutes, another $\$ 2.8$ billion would be exempted (out of the $\$ 24.1$ billion of imports in the "other" category), making total exemptions approximately $\$ 10$ bil-

57. H.R. 10914, Title III, Sec. 303(e); S. 2592, Title III, Sec. 303(e).

58. H.R. 10914, Title III, Sec. 301(b)(2)(B).

59. Ibid., Sec. 301(f).

60. Ibid., Sec. 301(d)(1)-(4). These exemptions would not apply, presumably, to automobiles imported into the United States under the Canadian auto agreement since no restrictions are involved.

61. Inadequate data on steel dictated excluding it from the exemptions considered in this analysis, and it is considered subject to rollback here. 
lion. This would reduce 1971 imports subject to rollback from the total import level of $\$ 45.5$ billion to $\$ 35.6$ billion.

Columns (5) and (6) of Table 10 show the average 1965-69 and 1971 quantities of U.S. imports in millions of 1958 dollars, and column (7) the ratio between them. However, trade will not be cut back for each country in proportion to the amounts indicated in column (7) because of the $\$ 10$ billion in exemptions. Columns (1), (3), and (4) give the value of U.S. imports in 1971 dollars, imports excluding exemptions, and the exemptions themselves. Columns (8) and (9) give the portions of trade affected and unaffected by the cutbacks.

The ratio of the proposed to existing 1971 total U.S. imports by country equals the cutback ratio in column (7) times the ratio of applicable to total trade in column (8) plus column (9). This is shown in column (10). The percentage decreases in the quantities of total imports are in column (11). For the EEC countries, the import cutbacks range from 20 to 31 percent; for EFTA countries, around 10 percent; for Canada, 29 percent; for Japan, 44 percent; and for the less developed countries (LDCs) (the bulk of the rest-of-the-world region), 13 percent.

The price elasticities of demand for U.S. imports by country, estimated using 1951-69 annual data, are shown in column (12). Column (13) gives the percentage increase in the price of U.S. imports by country, using the percentage decreases in the quantities in column (11) divided by the price elasticities.

Two types of price increases are calculated: those based on total trade (column 13) and those based on trade that is subject to the rollbacks (column 14). In the latter case, the prices of U.S. imports from twelve of the fifteen regions experience price increases of less than 20 percent. Low price elasticities of demand for imports from Canada and the LDCs cause the prices of their products to rise by 71 and 38 percent, respectively. The average import price increase for all products subject to the quantitative cutback is 36 percent. For simplicity, I assume that the supply elasticities of U.S. imports by country are high, so that the proportionate cutback in the quantities and the values of trade are the same.

Thus, a decrease in the value of total trade shown in column (15) is simply the quantity rollback in column (11) times the value of 1971 imports in column (1). The hardest-hit countries are Germany, with declines in exports to the United States of $\$ 1.1$ billion; Canada, with $\$ 3.7$ billion; Japan, with $\$ 3.2$ billion; and the LDCs, with $\$ 1.7$ billion. The total value of the 
Table 10. Effect on 1971 Import Levels of Quantitative Cutback to 1965-69 Levels Dollar amounts in millions

\begin{tabular}{|c|c|c|c|c|c|c|c|c|}
\hline \multirow[b]{2}{*}{ Country } & \multicolumn{4}{|c|}{ U.S. imports } & \multicolumn{2}{|c|}{$\begin{array}{c}\text { U.S. imports } \\
(1958 \text { dollars })\end{array}$} & \multirow{2}{*}{$\begin{array}{l}\text { Ratio of } \\
1965-69 \\
\text { to } 1971 \\
(5) /(6)\end{array}$} & \multirow{2}{*}{$\begin{array}{c}\text { Share of } \\
\text { trade } \\
\text { affected by } \\
\text { Burke- } \\
\text { Hartke } \\
(3) /(1)\end{array}$} \\
\hline & $\begin{array}{c}\text { Total, } \\
1971 \\
\text { imports }\end{array}$ & $\begin{array}{l}\text { Share of } \\
\text { total }\end{array}$ & $\begin{array}{l}\text { Imports } \\
\text { excluding } \\
\text { exceptions }\end{array}$ & $\begin{array}{l}\text { Exceptions } \\
(1)-(3)\end{array}$ & $\begin{array}{l}\text { Average } \\
\text { quantity } \\
1965-69\end{array}$ & $\begin{array}{c}1971 \\
\text { quantity }\end{array}$ & & \\
\hline $\begin{array}{l}\text { United Kingdom } \\
\text { Belgium } \\
\text { Denmark }\end{array}$ & $\begin{array}{r}\$ 2,461 \\
848 \\
286\end{array}$ & $\begin{array}{l}0.054 \\
0.019 \\
0.006\end{array}$ & $\begin{array}{r}\$ 2,193 \\
773 \\
270\end{array}$ & $\begin{array}{r}\$ 268 \\
75 \\
16\end{array}$ & $\begin{array}{r}\$ 1,647 \\
621 \\
189\end{array}$ & $\begin{array}{r}\$ 1,912 \\
802 \\
242\end{array}$ & $\begin{array}{l}0.861 \\
0.774 \\
0.781\end{array}$ & $\begin{array}{l}0.89 \\
0.91 \\
0.94\end{array}$ \\
\hline $\begin{array}{l}\text { France } \\
\text { Germany } \\
\text { Italy }\end{array}$ & $\begin{array}{l}1,080 \\
3,665 \\
1,405\end{array}$ & $\begin{array}{l}0.024 \\
0.080 \\
0.031\end{array}$ & $\begin{array}{l}1,010 \\
3,476 \\
1,211\end{array}$ & $\begin{array}{r}70 \\
189 \\
194\end{array}$ & $\begin{array}{r}703 \\
1,925 \\
967\end{array}$ & $\begin{array}{r}936 \\
2,846 \\
1,334\end{array}$ & $\begin{array}{l}0.751 \\
0.676 \\
0.725\end{array}$ & $\begin{array}{l}0.94 \\
0.95 \\
0.86\end{array}$ \\
\hline $\begin{array}{l}\text { Netherlands } \\
\text { Norway } \\
\text { Sweden }\end{array}$ & $\begin{array}{l}532 \\
172 \\
455\end{array}$ & $\begin{array}{l}0.012 \\
0.004 \\
0.010\end{array}$ & $\begin{array}{l}458 \\
168 \\
448\end{array}$ & $\begin{array}{r}74 \\
4 \\
7\end{array}$ & $\begin{array}{l}346 \\
137 \\
315\end{array}$ & $\begin{array}{l}448 \\
151 \\
359\end{array}$ & $\begin{array}{l}0.772 \\
0.908 \\
0.877\end{array}$ & $\begin{array}{l}0.86 \\
0.98 \\
0.98\end{array}$ \\
\hline $\begin{array}{l}\text { Switzerland } \\
\text { Canada } \\
\text { Japan }\end{array}$ & $\begin{array}{r}492 \\
12,723 \\
7,244\end{array}$ & $\begin{array}{l}0.011 \\
0.279 \\
0.159\end{array}$ & $\begin{array}{r}458 \\
11,737 \\
6,577\end{array}$ & $\begin{array}{r}34 \\
986 \\
667\end{array}$ & $\begin{array}{r}329 \\
7,027 \\
3,389\end{array}$ & $\begin{array}{r}337 \\
10,309 \\
6,530\end{array}$ & $\begin{array}{l}0.977 \\
0.681 \\
0.518\end{array}$ & $\begin{array}{l}0.93 \\
0.92 \\
0.91\end{array}$ \\
\hline $\begin{array}{l}\text { Australia } \\
\text { South Africa } \\
\text { Rest of world }\end{array}$ & $\begin{array}{r}621 \\
285 \\
13,277\end{array}$ & $\begin{array}{l}0.013 \\
0.006 \\
0.292\end{array}$ & $\begin{array}{r}301 \\
158 \\
6,321\end{array}$ & $\begin{array}{r}320 \\
127 \\
6,956\end{array}$ & $\begin{array}{r}389 \\
236 \\
9,193\end{array}$ & $\begin{array}{r}567 \\
301 \\
12,586\end{array}$ & $\begin{array}{l}0.686 \\
0.784 \\
0.730\end{array}$ & $\begin{array}{l}0.48 \\
0.55 \\
0.48\end{array}$ \\
\hline All countries & 45,546 & 1.000 & 35,559 & 9,987 & $\ldots$ & $\ldots$ & $\ldots$ & 0.78 \\
\hline
\end{tabular}

Sources: The 1971 trade data in columns (1)-(4) were provided by Mary Jane Wignot, Office of the Special Representative for Trade Negotiations. The import data for 1965-69 came from U.S. Department of Agriculture, Economic Research Service, Foreign Agricultural Trade of the United States, annual issues. The total country export price indexes used to deflate the value data, with $1958=100$, were computed from various issues of International Monetary Fund, International Financial Statistics. Price elasticities (column 12), based on annual data for 1951-69, are from Stephen P.

decrease in U.S. imports is $\$ 11.2$ billion, about 25 percent of total trade and 32 percent on trade affected by the Burke-Hartke rollbacks.

One caveat about Table 10: At the time of writing, data for the 1965-69 period were not available by country on the value of U.S. imports regulated by quotas. Also, the price indexes used to deflate the series included both quota and nonquota items. Including quota items probably leads to an underestimate of the actual Burke-Hartke cutback, since the quota price indexes presumably grow faster than the average. Using an index including these items to deflate the values of trade leads to an underestimate of the growth in the quantities of U.S. imports from 1965-69 to 1971, and hence an underestimate of the cutback.

In the tariff exercise performed in an earlier section, the only variation in the price declines in each category was due to differences in tariff rates. Thus, if the assumption of a high foreign supply elasticity for U.S. imports holds, the percentage declines in the import prices of dutiables depends only on the tariffs and is independent of the demand elasticities. Use of the 


\section{as Proposed in Burke-Hartke Legislation, by Country}

\begin{tabular}{|c|c|c|c|c|c|c|c|}
\hline \multirow[b]{2}{*}{$\begin{array}{c}\text { Share of } \\
\text { unaffected } \\
\text { trade } \\
1.0-(8)\end{array}$} & \multirow{2}{*}{$\begin{array}{c}(10) \\
\text { Ratio of } \\
\text { proposed to } \\
\text { actual } 1971 \\
\text { trade } \\
(7) \times(8) \\
+(9)\end{array}$} & \multirow{2}{*}{$\begin{array}{c}(11) \\
\\
\text { Percentage } \\
\text { decrease in } \\
\text { total trade } \\
{[1.0-(10)]} \\
\times 100\end{array}$} & \multirow{2}{*}{$\begin{array}{c}\text { (12) } \\
\text { Absolute } \\
\text { value of price } \\
\text { elasticity of } \\
\text { demand }\end{array}$} & \multicolumn{2}{|c|}{$\begin{array}{c}(13) \underset{(\text { percent })}{(14)} \\
\text { Price increase in U.S. } \\
\text { (pers }\end{array}$} & \multirow[b]{2}{*}{$\begin{array}{c}\text { Value of } \\
\text { decrease in } \\
1971 \text { imports } \\
(1) \times(11)\end{array}$} & \multirow[b]{2}{*}{$\begin{array}{l}\text { New value } \\
\text { of } 1971 \\
\text { imports } \\
(1)-(15)\end{array}$} \\
\hline & & & & $\begin{array}{c}\text { On } \\
\text { total } \\
\text { imports } \\
(11) /(12)\end{array}$ & $\begin{array}{c}\text { On } \\
\text { nonexempt } \\
\text { imports } \\
{[(1)-(7) /(12)]}\end{array}$ & & \\
\hline $\begin{array}{l}0.11 \\
0.09 \\
0.06\end{array}$ & $\begin{array}{l}0.876 \\
0.794 \\
0.793\end{array}$ & $\begin{array}{l}12.4 \\
20.6 \\
20.7\end{array}$ & $\begin{array}{l}1.55 \\
4.09 \\
1.11\end{array}$ & $\begin{array}{r}8.0 \\
5.0 \\
18.6\end{array}$ & $\begin{array}{r}9.0 \\
5.6 \\
19.8\end{array}$ & $\begin{array}{r}\$ 305 \\
175 \\
59\end{array}$ & $\begin{array}{r}\$ 2,154 \\
671 \\
226\end{array}$ \\
\hline $\begin{array}{l}0.06 \\
0.05 \\
0.14\end{array}$ & $\begin{array}{l}0.765 \\
0.692 \\
0.764\end{array}$ & $\begin{array}{l}23.5 \\
30.8 \\
23.6\end{array}$ & $\begin{array}{l}5.06 \\
2.50 \\
3.36\end{array}$ & $\begin{array}{r}4.6 \\
12.3 \\
7.0\end{array}$ & $\begin{array}{r}4.9 \\
12.8 \\
8.3\end{array}$ & $\begin{array}{r}254 \\
1,129 \\
332\end{array}$ & $\begin{array}{r}826 \\
2,536 \\
1,073\end{array}$ \\
\hline $\begin{array}{l}0.14 \\
0.02 \\
0.02\end{array}$ & $\begin{array}{l}0.803 \\
0.909 \\
0.879\end{array}$ & $\begin{array}{r}19.7 \\
9.1 \\
12.1\end{array}$ & $\begin{array}{l}2.98 \\
1.58 \\
3.35\end{array}$ & $\begin{array}{l}6.6 \\
5.8 \\
3.6\end{array}$ & $\begin{array}{l}7.7 \\
5.7 \\
3.5\end{array}$ & $\begin{array}{r}105 \\
16 \\
55\end{array}$ & $\begin{array}{l}429 \\
156 \\
400\end{array}$ \\
\hline $\begin{array}{l}0.07 \\
0.08 \\
0.09\end{array}$ & $\begin{array}{l}0.978 \\
0.706 \\
0.561\end{array}$ & $\begin{array}{r}2.2 \\
29.4 \\
43.9\end{array}$ & $\begin{array}{l}1.76 \\
0.45 \\
3.52\end{array}$ & $\begin{array}{r}1.3 \\
65.3 \\
12.5\end{array}$ & $\begin{array}{r}1.3 \\
71.1 \\
13.6\end{array}$ & $\begin{array}{r}11 \\
3,741 \\
3,180\end{array}$ & $\begin{array}{r}482 \\
8,982 \\
4,064\end{array}$ \\
\hline $\begin{array}{l}0.52 \\
0.45 \\
0.52\end{array}$ & $\begin{array}{l}0.848 \\
0.881 \\
0.870\end{array}$ & $\begin{array}{l}15.2 \\
11.9 \\
13.0\end{array}$ & $\begin{array}{l}1.0 \mathrm{~b} \\
1.20 \\
0.71\end{array}$ & $\begin{array}{r}15.2 \\
9.9 \\
18.3\end{array}$ & $\begin{array}{l}31.0 \\
18.3 \\
38.0\end{array}$ & $\begin{array}{r}94 \\
34 \\
1,726\end{array}$ & $\begin{array}{r}527 \\
253 \\
11,551\end{array}$ \\
\hline 0.22 & $\ldots$ & $\ldots$ & 1.53 & $\ldots$ & 35.9 & 11,216 & 34,330 \\
\hline
\end{tabular}

Magee, "Tariffs and U.S. Trade," A Study for the Council of Economic Advisers, Working Paper 14 (June 1972; processed). The calculations are based on data before rounding.

a. All elasticities in the column are negative.

b. This elasticity was statistically insignificant. However, I assume for simplicity that it equals 1 .

import elasticities reported on page 665 to calculate the percentage increase in the prices of importables in the United States as a result of the Burke-Hartke cutback would understate the actual price increase. The reason is that the distribution elasticities are less important when the price changes are more or less exogenously set (by tariff changes) whereas they must be incorporated in calculating an aggregate price elasticity if the components are endogenously determined. ${ }^{62}$

62. Sufficient conditions for the consistency of disaggregated price elasticities and an estimated aggregate price elasticity have been discussed in T. S. Barker, "Aggregation Error and Estimates of the U.K. Import Demand Function," in Kenneth Hilton and David F. Heathfield (eds.), The Econometric Study of the United Kingdom (Macmillan, 1970), pp. 115-43. An elaboration of this technique is discussed and applied to U.S. trade in Magee, "Tariffs and U.S. Trade." This problem was first brought to my attention in a paper by William H. White, "Bias in Export Substitution Elasticities Derived through Use of Cross Section Sub-Market Data" (International Monetary Fund, March 1970; processed). The total elasticity that is consistent with disaggregated data can be written as follows:

$$
e=\sum e_{i}\left(m_{i} / m\right) v_{i},
$$


The data in Table 10 can be used to calculate the implicit aggregate uniform price elasticity of demand associated with the Burke-Hartke rollback. Since the calculations are done at a disaggregated (country) level, the average import price increase incorporates the appropriate country distribution elasticities into the aggregate elasticity. Since the price of nonexempt imports rises by 36 percent and the quantity declines by 32 percent (11.22/ 35.56 ), the implicit total price elasticity is -0.89 . However, this number is lower than desirable for present purposes since it is based on price elasticities (column 12 of Table 10) that were estimated on total trade (including quota items). Assuming that the effective price elasticity of demand for quota items is 0 and using 0.16 for the 1971 weight of quota items in U.S. imports, the short-run elasticity for this exercise on nonquota imports is -1.06 , which for simplicity is taken as unity $(-1.0)$. The long-run import demand elasticities used above were approximately 2.5 times the short-run elasticities. Thus, the assumption in this section is that the long-run demand elasticity for imports is -2.5 .

Since the Burke-Hartke proposal reduces the quantity of dutiable imports by 32 percent (from $\$ 35.6$ billion in 1971 to $\$ 24.3$ billion), the price rises by 32 percent in the short run and by 12 percent in the long run. These are equivalent to 32 percent and 12 percent ad valorem tariff levels on top of existing tariffs. Since tariffs are eliminated under the Burke-Hartke proposals, the net welfare distortion of Burke-Hartke must be measured by calculating the total welfare cost from free trade levels and then subtracting the costs of existing tariffs.

The ad valorem average tariff rate on dutiable trade is now 6.8 percent $(2.5 / 36.4) \cdot 100$. This implies that the long-run and short-run ad valorem equivalents of the Burke-Hartke proposal above world prices are 41.0 percent and 19.6 percent, respectively. ${ }^{63}$ Equation (2) serves to calculate the

$$
\text { where } \begin{aligned}
e & =\text { total import price elasticity } \\
e_{i} & =\text { disaggregated elasticities } \\
\left(m_{i} / m\right) & =\text { share of category } i \text { in imports } \\
v_{i} & =\text { distribution elasticity } \\
& =\left(d p_{i} / p_{i}\right) /(d p / p) .
\end{aligned}
$$

The variable $v_{i}$ is called the distribution elasticity. It indicates the average percent variation in the price of category $i$ relative to the total price index, $p$. Since prices of items with high elasticities of demand vary much less than the aggregate index, $v_{i}$ will be lower for high-elasticity items than for low-elasticity items. This negative correlation between $e_{i}$ and $v_{i}$ lowers $e$.

63. One plus the ad valorem equivalents above world prices equals $(1.32)(1.068)=$ 1.410 , and $(1.120)(1.068)=1.196$. 
deadweight loss portion of the Burke-Hartke cutback. The free trade value of imports to be used in that formula equals $\$ 40.9$ billion in the short run and $\$ 50.1$ billion in the long run. ${ }^{64}$ Thus, the deadweight losses are as follows:

$$
\begin{array}{rlrl} 
& \text { Short run } & \text { Long run } \\
D W L & =0.5(0.410)^{2}(1)(40.9) & D W L & =0.5(0.196)^{2}(2.5)(50.1) \\
& =\$ 3.4 \text { billion } & & =\$ 2.4 \text { billion. }
\end{array}
$$

The long-run annual loss from the quota is less than the short-run loss: The higher elasticity of demand for imports plus the larger long-run free trade base is not sufficient to offset the smaller ad valorem equivalent tariff.

The second part of the loss to the United States from the quota is the tariff-equivalent revenue captured by foreign suppliers. It equals the ad valorem equivalent tariffs ( 0.410 and 0.196 , respectively) times the restricted levels of imports under the cutback ( $\$ 24.3$ billion), or $\$ 10.0$ billion in the short run and $\$ 4.8$ billion in the long run. Assuming that half of these amounts are captured by foreign suppliers, the additional social loss is $\$ 5.0$ billion in the short run and $\$ 2.4$ billion in the long run, for a total annual cost of the cutback of $\$ 8.4$ billion in the short run and $\$ 4.8$ billion in the long run.

In Table 11, the short- and long-run effects of the Burke-Hartke cutback are converted to present values at 4 percent, 7 percent, and 10 percent. Remember that the discount rates are roughly equal to the rate of capitalization less the growth rates of quota imports in the absence of restrictions. Since this rate is likely to be high for a number of years, 4 percent is probably the most reasonable rate. It should be emphasized that the calculations performed here assume no retaliation against U.S. exports, and thus minimize the potential costs.

As in the tariff elimination case, the shift of factors into import-competing industries also creates costs. Assuming that the entrance into industries under Burke-Hartke takes only half as long as the departure from them under freer trade, considered in Table 7, and with the directly competitive and other import categories averaged, present values of the costs of job

64. Directly competitive dutiable imports increase by $\$ 2.7$ billion in the short run and $\$ 8.0$ billion in the long run with tariff elimination (see Table 4). Other imports increase by roughly $\$ 2.8$ billion in the short run and $\$ 7.0$ billion in the long run. Thus, nonquota imports increase by 15.1 percent in the short run and 41.2 percent in the long run so that free trade nonquota imports to which Burke-Hartke would apply are $\$ 40.9$ billion in the short run and $\$ 50.1$ billion in the long run. 
Table 11. Annual Costs to the United States, from 1971 Base; of the Burke-Hartke Cutback on Imports, and Present Values, by Alternative Discount Rates

Billions of dollars

\begin{tabular}{|c|c|c|c|c|}
\hline \multirow[b]{2}{*}{ Year } & \multirow{2}{*}{$\begin{array}{l}\text { Annual } \\
\text { cost of the } \\
\text { cutback }\end{array}$} & \multicolumn{3}{|c|}{ Present value of the cutback } \\
\hline & & $4 \%$ & $7 \%$ & $10 \%$ \\
\hline 1 & 8.4 & 8.4 & 8.4 & 8.4 \\
\hline 2 & 7.5 & 7.2 & 7.0 & 6.8 \\
\hline 3 & 6.6 & 6.1 & 5.7 & 5.5 \\
\hline 4 & 5.7 & 5.1 & 4.7 & 4.3 \\
\hline 5 & 4.8 & 4.1 & 3.6 & 3.3 \\
\hline Total, 1 to 5 & $\ldots$ & 30.9 & 29.4 & 28.3 \\
\hline Total, 1 to 5 , including job-change costs & $\ldots$ & 31.4 & 29.9 & 28.8 \\
\hline 6 to 10 & $\ldots$ & 18.2 & 14.9 & 12.5 \\
\hline 11 to 15 & $\ldots$ & 14.9 & 10.6 & 7.7 \\
\hline After 15 & $\ldots$ & 69.6 & 26.9 & 12.5 \\
\hline All years & .. & 133.6 & 81.8 & 61.0 \\
\hline All years, including job-change costs & $\ldots$ & 134.1 & 82.3 & 61.5 \\
\hline
\end{tabular}

Source: The job-change costs and the annual cost for year one are developed in the text accompanying this section. The annual cost is discounted at 6 percent for future years.

changes per $\$ 1$ billion change in output are $\$ 45$ million at 4 percent, $\$ 43$ million at 7 percent, and $\$ 40$ million at 10 percent. If the expansion of domestic production roughly equals the reduction in imports of $\$ 11.2$ billion, ${ }^{65}$ the present values of the job-change costs associated with the Burke-Hartke increase in domestic production are $\$ 509$ million at 4 percent, $\$ 486$ million at 7 percent, and $\$ 452$ million at 10 percent. These changes are small relative to the costs noted in Table 11. At 4 percent, the present cost of the Burke-Hartke cutback, including these job-change costs, is $\$ 134$ billion.

\section{PROPORTIONAL QUOTAS}

A second feature of Title III of the Burke-Hartke trade proposal required that after 1972 trade had been cut back to the 1965-69 levels, the ratio of imports to domestic production could not exceed the 1965-69

65. This is an extremely rough estimate, since it assumes that the reduction in imports due to reduced demand equals the redistribution effect plus the effect of production deadweight losses. 
ratio. This means that imports could grow no faster than domestic production. Starting from a 1958-61 base, imports in directly competitive areas grew by approximately 10 percent per year until 1969, while domestic production of these goods grew by just over 5 percent. However, import growth was accelerated over this period by a number of transitory factors, so that the calculation of the restrictive effect of the proportional quota assumes that imports grow at only 1.5 times domestic production. This, in fact, equals the income elasticity of demand for imports estimated over the period 1951-69.66 This analysis provides a conservative estimate of the costs of the proportional quota by assuming that the long-run growth of import-competing production equals real GNP growth and real imports grow at 1.5 times that rate. From 1950 to 1971, U.S. real GNP grew at 3.55 percent per annum. The income elasticity factor implies import growth of 5.33 percent per annum.

The technique used for measuring the effects of the proportional quota is to assume that imports would grow at 5.33 percent in the absence of the quota and 3.55 percent with it. The gap between the actual import level in year $i$ and the restricted quota level, $R_{i}$, is given by

$$
R_{i}=\left[(1.0533)^{i}-(1.0355)^{i}\right] V_{b},
$$

where $V_{b}$ is the value of the imports under consideration in the base period. To provide an estimate of the cost of proportional quotas that is independent of the Burke-Hartke cutback, calculations here assume that the nonexempt 1971 level of $\$ 35.6$ billion in imports is the base. Columns (1) and (2) of Table 12 show the actual and limited imports starting from this base. Column (3) is the percentage decrease in the quantity of imports due to the proportional quota. Since the equivalent tariff changes each year, the shortrun elasticity of -1.0 used in the previous section is applied. This means that column (3) is also the ad valorem equivalent tariff implied by the quota. Column (4) gives the annual deadweight loss and column (5) the tariffequivalent revenue lost to foreigners, who are assumed to capture half of it. The total costs of the quota are in column (6), and their present values using 4, 7, and 10 percent discount factors are shown in columns (7)-(9). Since growth is already accounted for, 7 percent is probably a reasonable discount rate. The calculations were not carried past the fifteenth year because

66. See Houthakker and Magee, "Income and Price Elasticities in World Trade," and Magee, "Theoretical and Empirical Examination of Supply and Demand Relationships." 


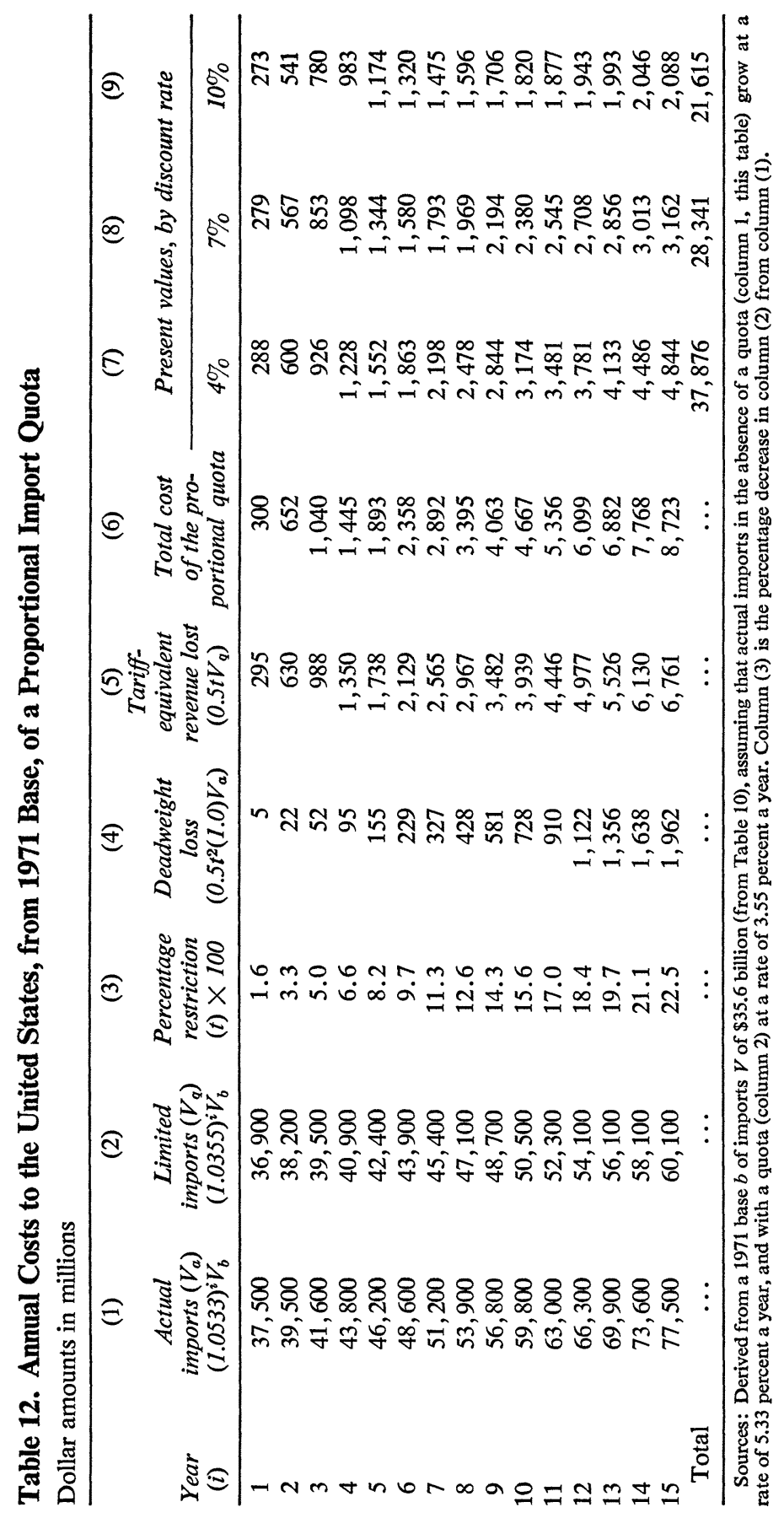


losses grow more rapidly than the discount rate. Even then, at 7 percent, the present cost of the proportional quota is $\$ 28.3$ billion; it has small short-run costs but the long-run costs are high because of the cascading restrictive effect.

\section{Qualifications}

The calculations in this paper should be viewed as ballpark estimates of the welfare effects of trade restrictions-they are subject to great uncertainty. At least four nonquantifiable factors indicate that the numerical estimates presented here understate the true costs of trade restrictions. First, except for some mechanical exercises, this paper has ignored some important dynamic gains from free trade. Both economists and the public at large broadly agree that economic growth leads to an increase in welfare. However, Johnson has shown that if economic growth shifts resources toward protected industries, it can actually serve to worsen welfare rather than augment it. ${ }^{67}$ This occurs because the benefits of growth are offset by the waste of additional production in protected industries.

A second qualitative factor is economies of scale. In areas where economies of scale are important, the production gains are greater the larger the size of the market. Clearly, these production gains will be larger in an open world economy than in one of many small submarkets separated by high tariffs or other restrictions. Furthermore, the framework used here cannot serve to quantify the welfare gains from expanded markets in areas of declining costs.

Third, the effect of trade on the antitrust problem should also be considered. If U.S. car manufacturers and automobile workers faced no competition from imported vehicles, the results of wage negotiations and the increases in both the size and the price of automobiles in the United States would worsen. Thus, free trade is a stimulus for greater competition and industrial efficiency in the United States. Quotas are an especially bad form of restriction because they may convert a potential into an actual monopoly.

67. Harry G. Johnson, "The Possibility of Income Losses from Increased Efficiency or Factor Accumulation in the Presence of Tariffs," Economic Journal, Vol. 77 (March 1967), pp. 151-54. 
Finally, Tullock has enumerated other costs related to protection. ${ }^{68}$ First, the system imposes administrative costs. Second, if public funds are less efficiently engaged than private funds, the transfer of funds from individuals to the government will cause losses not measured in the deadweight loss calculations discussed earlier. Third, the redistribution from consumers to producers may not increase the welfare of the latter since they will be willing to invest resources in lobbying for protection until the marginal return on the last dollar so invested is equal to the likely return of the transfer. Consumers, on the other hand, interested in protecting their own surplus, may be willing to invest similarly. While these expenditures may be rational from the point of view of the economic agents involved, they are wasteful for society as a whole. This is particularly true since a highly efficient industrial organization and successful lobbying for protectionism may be very close substitutes. To the extent that firms believe that these two things are close substitutes, industrial efficiency is impaired.

This paper has not considered a full general equilibrium approach to trade restrictions, ${ }^{69}$ which includes the effects of monetary policy and financial assets. It has examined only the cost of trade restrictions. But since policy analysis involves relative comparisons, in order to decide whether an alternative policy should be used to achieve the goal of trade restrictions, the present value of its costs should be compared with the costs calculated here. The high costs of one policy have no meaning in isolation from cost comparisons with others.

This paper has already addressed the argument that trade policy should be used to correct the aggregate unemployment problem. A word is in order on the effects of trade barriers on the U.S. distribution of income. Trade liberalization would improve the U.S. job mix, with a shift toward a larger proportion of higher-wage jobs. ${ }^{70}$ But because it would alter the job

68. Gordon Tullock, "The Welfare Costs of Tariffs, Monopolies, and Theft," Western Economic Journal, Vol. 5 (June 1967), pp. 224-32.

69. See, for example, Michael Mussa, "Tariffs, the Distribution of Income, and the Balance of Payments" (paper delivered to the Workshop in International Economics, University of Chicago, July 18, 1972; processed), and the studies on real balances and currency devaluations in the extensive work by Rudiger Dornbusch, especially "Devaluation, Relative Prices and the Real Value of Money," Report 7130 (University of Chicago, Center for Mathematical Studies in Business and Economics, June 1971; processed). See also H. David Evans, A General Equilibrium Analysis of Protection: The Effects of Protection in Australia (Amsterdam: North-Holland, 1972).

70. As noted earlier, production wage rates per hour in 1967 were $\$ 3.16$ in the export industries and \$2.66 in import-competing industries. 
mix, a reduction in trade barriers would probably lead to a redistribution of income away from low-wage earners. In this context trade restrictions are probably progressive taxes. There are several exceptions to this rule. First, very high wage rates are paid in some quota areas: Data from the Trade Relations Council show that in 1967 wages in SIC 29, petroleum and coal, were $\$ 3.89$ per hour, and in SIC 3312, blast furnaces and steel mills, they were $\$ 3.98$ per hour. There are also some low wage rates in areas where restrictions on U.S. exports (particularly agricultural) are high. Second, Norman S. Fieleke has found that the U.S. tariff structure is slightly regressive on the consumption side. ${ }^{71}$ The regressivity is probably not great enough to offset the progressivity on the income side, however. Thus, the gains from freer trade are partially offset, in the absence of fiscal mechanisms to compensate those who lose from it, by a less equitable distribution of income.

\section{Summary}

The quantitative findings in this study are summarized in Table 13. They indicate the following costs to the United States of existing and proposed trade restrictions:

First, the average annual cost of U.S. import restrictions is $\$ 3.3$ billion to $\$ 5.0$ billion. The bulk of this is due to quotas and quantitative restrictions. In the short run (one to five years), the gains from eliminating tariffs on directly competitive and other nonquota imports is partially offset by $\$ 330$ million per year in labor transition costs. After transition costs, the United States could gain $\$ 2.7$ billion to $\$ 3.6$ billion per year by eliminating quotas.

Second, the present discounted value of the costs of restrictions on nonquota U.S. imports is $\$ 33.1$ billion. If these restrictions were eliminated, over a third of the gain would be obtained before the fifteenth year. The present value of the cost of U.S. quota restrictions is $\$ 88$ billion; if they were eliminated, U.S. welfare would increase in present value by nearly $\$ 37$ billion before the fifteenth year.

Third, foreign tariffs on exports of manufactured goods cost the United States relatively little $-\$ 300$ million to $\$ 500$ million per year, or a present value of $\$ 11.4$ billion. However, foreign restrictions on U.S. agricultural

71. "The Incidence of the U.S. Tariff Structure on Consumption," Public Policy, Vol. 19 (Fall 1971), pp. 639-52. 


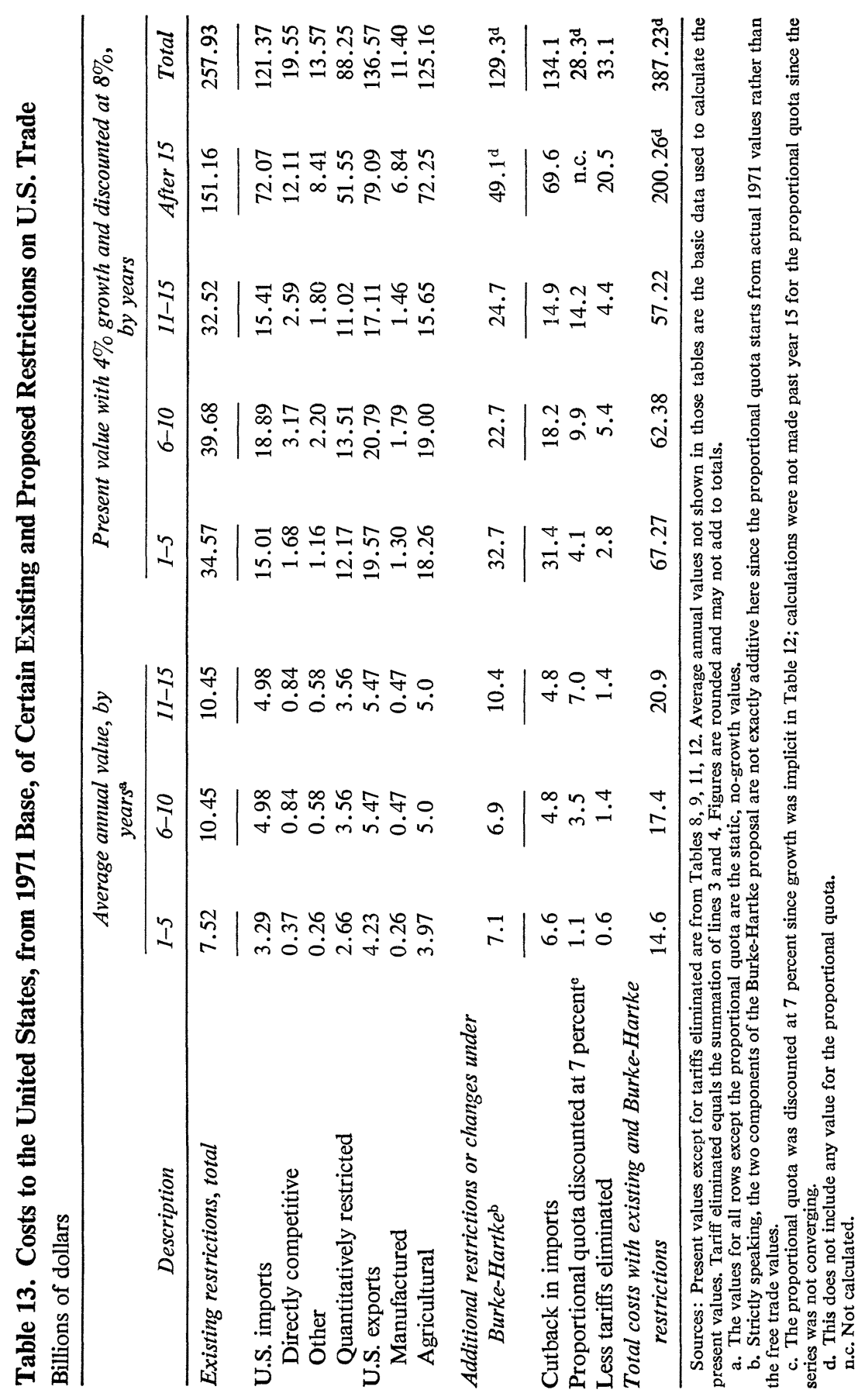


exports cost the nation $\$ 4$ billion to $\$ 5$ billion per year; this present discounted cost is $\$ 125$ billion and if it were eliminated, U.S. welfare would increase by $\$ 53$ billion within fifteen years.

Fourth, the total costs to the United States of existing tariff and quota barriers to trade average $\$ 7.5$ billion to $\$ 10.5$ billion per year. The present value of these costs is $\$ 258$ billion, $\$ 107$ billion of which is imposed before the fifteenth year.

Fifth, the total welfare cost to the United States of the Burke-Hartke cutback of U.S. imports from 1971 to $1965-69$ levels would be $\$ 3.4$ billion to $\$ 6.0$ billion per year. ${ }^{72}$ These imply a present value of $\$ 101$ billion, $\$ 52$ billion of which accrues in the first fifteen years after enactment.

Sixth, the proportional quota provision of the Burke-Hartke proposal would cost the United States $\$ 1.1$ billion per year in the first five years, $\$ 3.5$ billion per year in the second five years, and $\$ 7.0$ billion per year in the third five years after enactment. The present discounted value of these costs is $\$ 28$ billion within the first fifteen years. The calculations were not carried beyond that point because the losses were growing faster than the discount rate. This makes the proportional quota an especially dangerous form of restriction because of the cascading loss effect and the political tendency to keep quotas on long after they have achieved even short-run objectives.

Seventh, after subtracting the costs of the tariffs eliminated with BurkeHartke enactment, the net additional welfare cost of the proposal is $\$ 6.9$ billion to $\$ 10.4$ billion per year, or a present discounted value of $\$ 129$ billion, $\$ 80$ billion of which comes within the first fifteen years after enactment.

Finally, if Burke-Hartke were enacted, the total annual measured costs of restrictions on U.S. trade would be $\$ 15$ billion to $\$ 21$ billion per year; this has a present value of $\$ 387$ billion, $\$ 187$ billion of which would come in the next fifteen years. These calculations emphasize that quotas impose greater costs than tariffs because (1) foreigners capture part of the revenue that would have been generated by an equivalent tariff; (2) quotas stimulate monopoly behavior; (3) they hide the actual rate of protection given, which tends to be high; and (4) this implicit rate of protection usually grows through time. The last two points are important since the efficiency losses of all restrictions are proportional to the square of the rate of protection: Doubling restrictions quadruples the social costs.

72. These numbers equal the "cutback" line in Table 13 minus the "tariffs eliminated." 


\section{Comments and Discussion}

C. Fred Bergsten: I would like to stress and discuss further Magee's own warning that the gains of free trade calculated in the paper grossly underestimate the actual gains to the United States. As Magee mentioned, three major elements are omitted in his analysis-dynamic effects, economies of scale, and monopoly effects. These may provide very large additional benefits that should be added to the overall estimate of the potential gains from free trade. Preservation of competition is particularly important for the United States because some of the quota items, especially steel, are the products of highly oligopolistic industries in which foreign supplies may be the only source of real competitive pressure. The sectoral effects implied by Magee also merit special attention: The existing restrictions were costing consumers about $\$ 18$ billion per year, a bit more than the estimate in my own earlier paper cited by Magee because of his higher estimate of the consumer costs of present U.S. tariffs, while their benefits accrued to a limited number of special interests, before the administration wisely began to liberalize the oil and meat quotas to help fight inflation.

Magee's handling of the "tariff-equivalent" revenue issue should be emphasized. When tariffs are increased, part of the reduction in consumer surplus is captured by the additional tariff revenue the government collects; the result is "only" a transfer within the economy. But with quotas, the scarcity premiums that drive up prices must be divided between U.S. importers and foreign exporters, and the division is indeterminate. The foreign supplier always gets some share of the higher price triggered by the quota, and may even get all of it. Foreign suppliers are particularly likely to capture the larger part of the reduced U.S. consumer surplus under the favored new approach of "voluntary" export restraints, where the foreign country rather than the importing country administers the controls. In the case of 
the textile restraints, for example, Japanese firms with quota allocations are selling export tickets to one another (just as oil importers sell them to one another in this country). The price of the tickets derives from the scarcity premiums, suggesting that most if not all of the price increases from the U.S. quotas are being captured by Japanese producers rather than being transferred within the U.S. economy. This transfer from U.S. consumers to foreign exporters must be added to the deadweight loss in calculating the national loss to the United States from the quotas.

Perhaps the most important reason that the gains from free trade may be understated by Magee is that trade policy is unstable. The United States is virtually certain to get increased protectionism unless trade is liberalized. Thus any calculation of the benefits from reducing tariffs and other trade barriers must include the avoidance of the costs of increasing tariffs or quotas such as those proposed in the Burke-Hartke bill. Indeed, when the administration asks for new trade negotiating authority, its major motive is to avoid the Burke-Hartke bill. If it were necessary to try to eliminate tariffs completely in order to head off the Burke-Hartke quotas, as some administration officials have implied, the gains from free trade would equal, at a minimum, the sum of Magee's calculations of the costs of present tariffs plus the cost of Burke-Hartke itself.

Magee's calculations also have interesting implications for the feasibility of a new reciprocal trade negotiation. They suggest that the elimination of duties by the United States would raise U.S. imports by about $\$ 15$ billion annually over the longer run ( $\$ 8$ billion of "competitive" imports and $\$ 7$ billion of "noncompetitive" imports). The elimination of foreign duties would raise U.S. exports by roughly the same amount ( $\$ 6$ billion for manufactured exports for industries where exports were a substantial portion of sales, $\$ 5$ billion for agricultural exports, and some additional amount for the remaining one-half of all manufactured exports). Thus a move to eliminate all duties would appear to come reasonably close to meeting the test of reciprocity, at least from the standpoint of the United States.

Lawrence Krause: Magee's effort to calculate the incalculable is the first serious attempt to measure the effects of trade restrictions and it deserves to be encouraged. Of course, a lot of judgments are called for along the way in making these calculations. Although I trust Magee to make these judgments, my guess is that the losses due to existing restrictions are somewhat overstated in his paper. 
Magee's discussion and estimation of welfare concentrate on the economic inefficiency side of the story and virtually ignore the income redistribution side. The gainers and losers are not the same people, so there are genuine redistributive effects. One can argue that another way to offset the redistribution can always be found, but that is a cop-out. The political system will not provide full compensation for the losers, and the problem cannot be assumed away. My guess is that the income redistribution produced by the tariff system yields some positive welfare gain. In any case, the actual distributive effects need to be investigated and taken into account.

No matter how hard one tries to give the devil his due, I think Magee is absolutely correct in rejecting the unemployment argument in favor of trade restrictions. Fundamentally, trade restrictions are always inflationary and the only reason we have excessive overall unemployment is because of the inflation problem. Furthermore, the unemployment argument for trade restrictions supposes that job opportunities must be created in specific products (generally manufactured ones) where excess capacity exists. That is not the way cyclical recoveries in fact create jobs. During the past twelve months, manufacturing output has grown more rapidly than overall output, but the increase in employment in manufacturing has been only 500,000 , or less than 3 percent, compared with an overall increase of 2.4 million, or fully 3 percent.

A word is in order regarding the use of trade restrictions as means of accomplishing social goals. For example, many argue that oil quotas may be justified for national defense. In fact, they have worked in the wrong direction. What could be a stranger policy than using more domestic oil in peaceful times instead of saving it for national defense? On the other hand, Magee's infant industry argument cannot be dismissed simply on the grounds that a subsidy is a better mechanism; one must recognize the distorting effect of the extra taxes that would be required to produce the revenues to pay the subsidy. More generally, any move toward free trade would require customs revenue to be replaced by some other taxes, which may create consumption distortions that in part offset the gain.

I think the studies of the impact of existing quotas that Magee relies on grossly exaggerate the costs. The key assumption in these studies relates to the foreign supply elasticity to the United States and is weakest when perfect elasticity is assumed (as is often the case). These are managed markets that cannot be described adequately by elasticity parameters. Quota-free oil imports into the United States would mean a major institutional change 
in the world oil market, and one cannot reasonably assume that the price the United States would pay for imported oil would be unaffected. Magee finds the greatest costs by far on the quota side, but I seriously doubt the quality of the calculations he has to rely on. The estimates Magee uses for the benefits to the United States from increased agricultural exports if barriers were removed are probably just as shaky as those for the costs of import quotas. But I believe they convey the right message: Here is the most significant potential welfare gain to the United States from freer trade.

When one looks at the side of increased restrictions such as the BurkeHartke bill, the quantitative economic costs are not as important as the political impact. Burke-Hartke would make foreign trade policy a strictly domestic issue, unilaterally set by the United States with no further negotiations with other countries. This arrangement would have tremendous implications for international economic relations that cannot be captured in any estimate of the welfare loss.

I conclude that moving to freer trade may be worth something, but not a great deal; however, more restrictions may cost a very great deal indeed. Therefore, we should want to stay just about where we are. But, as Bergsten pointed out, we cannot stay where we are because the political situation on trade policy is basically unstable. We have to negotiate in order to avoid going backward. But we should not want to achieve completely free trade, because we could only backslide thereafter. We should really want to negotiate forever, reaching agreements before presidential elections to demonstrate that we have not merely wasted time and effort.

\section{General Discussion}

Paul Wonnacott shed light on why the welfare costs of existing tariffs tended to appear relatively small. He emphasized the point that the welfare triangles depend on the square of the tariff rate and thus when tariffs are cut by 50 percent, the welfare costs are reduced by 75 percent. In contrast to quotas, which have grown in importance, tariffs have been cut substantially since the 1930s; and consequently their remaining welfare costs are understandably small.

A number of participants commented on the importance of various factors that are omitted in Magee's analytical framework. Wonnacott felt that economies of scale were particularly important benefits of world markets, 
especially for certain U.S. exports like aircraft. Lawrence Klein mentioned that other types of U.S. trade restrictions can, like imports and quotas, have significant welfare costs. Among these he pointed to restrictions on the use of foreign-flag vessels and export promotion subsidies such as DISC. On the other hand, Klein questioned the assumption that foreign supply to the United States is highly elastic; that did not square with the evidence following our devaluation, when many foreign producers simply cut their export prices. Alfred Reifman was concerned that the estimated cost of the BurkeHartke proportional quota provision underestimated the impact of this seemingly reasonable provision. A ceiling that prevented each type of import from increasing its share of the U.S. market would soon restrict imports as sharply as the original cutback to 1965-69 average levels, since, for many goods, imports could be expected to continue to rise much faster than domestic production. Reifman also suggested that the Common Market experience might be studied to appraise the magnitude of dislocation costs involved in moving toward free trade. It was his impression that the evidence was reassuring.

Magee's treatment of job dislocation costs evoked a number of comments. Wonnacott stressed that increased imports can compete either with industries that are experiencing excess demand or with those that have idle resources. Increased imports that alleviate shortages in bottleneck areas can ease overall inflationary pressures and thereby make it possible to have less restrictive fiscal and monetary policies, and therefore higher levels of economic activity. In that sense, such additional imports can actually create jobs. On the other hand, if pockets of excessive unemployment exist in certain industries, additional imports that compete with these industries would clearly subtract from the aggregate employment total. William Nordhaus complimented Magee for making a genuine effort to examine the distribution problem and to identify the industries that would have increased unemployment. On the one hand, Nordhaus felt that Magee might be overstating the increase in unemployment due to dislocation by ignoring the normal process of attrition of workers through voluntary quits and retirement; to the extent that attrition brought down the employment total over time, the reduced employment needs of the industry would not increase turnover or layoffs. On the other hand, Nordhaus was concerned that the costs were measured entirely in terms of unemployment and ignored the possibility that people who were laid off might on balance have to take lower-paid jobs as a substitute. 
The discussion also focused on Magee's procedures of discounting and capitalizing the streams of benefits and costs over time. Franco Modigliani suggested that the proper interest rate should be a social measure of impatience since the measurements dealt with welfare effects. He felt that 6 percent was roughly the right real rate of interest to discount for impatience, but he questioned whether the process of taking present values was the best way to make the calculations. Magee felt that this technique was a useful way of looking at the problem because of the sharply contrasting time profiles of costs and benefits of trade restriction and trade expansion. 